\title{
Isolation, structure elucidation and conformational regulation of myropeptins, lipopeptides from a fungus Myrothecium roridum
}

\author{
Aya Yoshimura ${ }^{1,4}$, Shinichi Nishimura ${ }^{1,5 *}$, Takehiro Suzuki ${ }^{2}$, Akira Hattori ${ }^{1}$, \\ Naoshi Dohmae ${ }^{2}$, Taira Kato ${ }^{3}$, Hideaki Kakeya ${ }^{1 *}$
}

1. Department of System Chemotherapy and Molecular Sciences, Division of Bioinformatics and Chemical Genomics, Graduate School of Pharmaceutical Sciences, Kyoto University,

$$
\text { Kyoto 606-8501, Japan }
$$

2. Biomolecular Characterization Unit, RIKEN Center for Sustainable Resource Science,

2-1 Hirosawa, Wako, Saitama 351-0198, Japan

3. Research \& Development Division, MicroBioPharm Japan Co Ltd.,

156 Nakagawara, Kiyosu-shi, Aichi, 452-0915 Japan

4. Current affiliations: Department of Chemistry, Princeton University, Princeton,

New Jersey 08544, United States

5. Current affiliations: Department of Biotechnology, The University of Tokyo, 1-1-1 Yayoi, Bunkyo-ku, Tokyo 113-8657, Japan; Collaborative Research Institute for Innovative Microbiology, The University of Tokyo 1-1-1 Yayoi, Bunkyo-ku, Tokyo 113-8657, Japan

Shinichi Nishimura (anshin@mail.ecc.u-tokyo.ac.jp)
Hideaki Kakeya (ㄷseigyo-hisyo@ pharm.kyoto-u.ac.jp)

Supplementary methods: page S2-S4

Supplementary table: page S5

Supplementary figures: page S6-S11

References for supplementary information: page S12

NMR spectroscopic data: page S13-S28 


\section{Supplementary methods}

\section{General procedure}

All reagents and solvents were used as received from commercial suppliers and were used without further purification. IR spectra were measured using an FTIR spectrometer equipped with ZnSe ATR plate. Optical rotations were determined using the sodium D line (589 $\mathrm{nm})$. NMR spectra were measured on a $500 \mathrm{MHz}$ instrument (ECA-500, JEOL). ${ }^{1} \mathrm{H}$ and ${ }^{13} \mathrm{C}$ chemical shifts are shown relative to the solvent; $\delta_{\mathrm{H}} 2.50$ and $\delta_{\mathrm{C}} 39.5$ for DMSO- $d_{6}$ and $\delta_{\mathrm{H}} 3.31$ and $\delta_{\mathrm{C}}$ 49.0 for $\mathrm{CD}_{3} \mathrm{OH} / \mathrm{CD}_{3} \mathrm{OD}$. Chemical shifts $(\delta)$ are shown in parts per milliom (ppm) and coupling constants $(J)$ are in hertz $(\mathrm{Hz})$. The following abbreviations are used to describe multiplicities: $\mathrm{s}=$ singlet, $\mathrm{d}=$ doublet, $\mathrm{dd}=$ double doublets, $\mathrm{q}=$ quartet, $\mathrm{m}=$ multiplet. Mass spectral data were collected with FAB MS (JMS-700, JEOL), ESI IT-TOF MS (SHIMADZU), MALDI-TOF MS (ultraflextreme, Bruker daltonics), or Q-Exactive mass spectrometer (Thermo Fisher Scientific, Inc.). Flash column chromatography was performed over Silica Flash F60 (SiliCycle) using an elution system as described for each experiment. The CD spectra were recorded on a JASCO (Tokyo, Japan) model J-720 dichrograph. Cylindrical, fused quarts cells of $1.0 \mathrm{~mm}$ path lengths were employed. The data in solution are expressed in terms of $[\theta] \mathrm{T} \times 10^{-3}$, the total molar ellipticity $\left(\mathrm{mdeg} \cdot \mathrm{cm}^{2} \cdot \mathrm{dmol}^{-1}\right)$.

\section{Isolation of myropeptins $A_{1}(1), A_{2}(2)$ and myropeptin $B(3)$.}

Five liter of culture broth of a fungus Myrothecium roridum F27113 was extracted with $n$ - $\mathrm{BuOH}$ and concentrated in vacuo to obtain a crude residue $(4.38 \mathrm{~g})$. The residue was dissolved in $90 \% \mathrm{MeOH}$, which was washed with $n$-hexane three times. Water was added to the $90 \% \mathrm{MeOH}$ layer to make a $60 \% \mathrm{MeOH}$ solution, which was extracted with $\mathrm{CHCl}_{3}$ three times. The $\mathrm{CHCl}_{3}$ extracts were combined and concentrated in vacuo. The residue was dissolved in $\mathrm{CHCl}_{3}-\mathrm{MeOH}$ (50:50) and subjected to a LH-20 gel filtration column. Fractions containing myropeptins were combined and chromatographed on a ODS column with $\mathrm{MeOH}-\mathrm{H}_{2} \mathrm{O}$ (20:80 to 100:0). Fractions eluted by $\mathrm{MeOH}-\mathrm{H}_{2} \mathrm{O}$ (100:0) were subjected to RP HPLC on Cosmosil $5 \mathrm{C}_{8}$-MS $(\phi 20 \times 250 \mathrm{~mm})$ with $\mathrm{MeCN}-\mathrm{H}_{2} \mathrm{O}$ (45:55 to 100:0). Fractions containing myropeptins were subjected to RP HPLC on Cosmosil 5C $\mathrm{C}_{18}$-AR-II $(\phi 20 \times 250 \mathrm{~mm})$ with $\mathrm{MeCN}-\mathrm{H}_{2} \mathrm{O}(60: 40)$ containing $0.1 \%$ TFA to afford myropeptin A $(\mathbf{1}, \mathbf{2}, 35.6 \mathrm{mg})$ and myropeptin B $(\mathbf{3}, 59.0 \mathrm{mg})$ as colorless amorphous solids, respectively.

Myropeptin $\mathrm{A}_{1}(\mathbf{1})$ and $\mathrm{A}_{2}(\mathbf{2})$ : $[\alpha]_{\mathrm{D}}{ }^{20}+12.18$ (c 0.42, MeOH); IR (neat) 3731, 2983, 2461, 1640, 1421, $1200 \mathrm{~cm}^{-1}$; HRMS (ESI) $\mathrm{m} / z, 927.5766[\mathrm{M}+2 \mathrm{H}]^{2+}$ calcd for $\mathrm{C}_{44.5} \mathrm{H}_{77} \mathrm{~N}_{10} \mathrm{O}_{11}, 927.5768$ (myropeptin $\mathrm{A}_{1}(\mathbf{1})$ ); $\mathrm{m} / z 920.5692[\mathrm{M}+2 \mathrm{H}]^{2+}$ calcd for $\mathrm{C}_{44} \mathrm{H}_{76} \mathrm{~N}_{10} \mathrm{O}_{11}, 920.5690$ (myropeptin $\mathrm{A}_{2}$ (2)).

Myropeptin B (3): $[\alpha]_{\mathrm{D}}^{20}+1.56$ (c 0.36, MeOH); IR (neat) 3286, 2984, 1647, 1543, $1173 \mathrm{~cm}^{-1}$; HRMS (ESI) $m / z 1710.0571[\mathrm{M}+\mathrm{H}]^{-}$calcd for $\mathrm{C}_{83} \mathrm{H}_{141} \mathrm{~N}_{18} \mathrm{O}_{20}, 1710.0575$.; ${ }^{1} \mathrm{H}$ and ${ }^{13} \mathrm{C}$ NMR, see Table 1.

\section{Advanced Marfey's analysis of myropeptin B (3).}

To a solution of $\mathbf{3}\left(0.17 \mathrm{mg}, 9.94 \times 10^{-5} \mathrm{mmol}\right)$ was added $6 \mathrm{~N} \mathrm{HCl}(0.2 \mathrm{~mL})$, which was reacted for $24 \mathrm{~h}$ at $110{ }^{\circ} \mathrm{C}$. The reaction mixture was dried in vacuo. The obtained hydrolysate was dissolved in $\mathrm{H}_{2} \mathrm{O}(50 \mu \mathrm{L})$, to which $1 \mathrm{M} \mathrm{NaHCO}_{3}(20 \mu \mathrm{L})$ and L- or D-FDLA $(1 \% \mathrm{w} / \mathrm{v}$ in 
acetone, $100 \mu \mathrm{L}$ ) were added, and the mixture was stirred for $1 \mathrm{~h}$ at $60{ }^{\circ} \mathrm{C}$. The solution was neutralized with $1 \mathrm{~N} \mathrm{HCl}(20 \mu \mathrm{L})$, evaporated, and then dissolved in $\mathrm{MeCN}$. The derivatives were analyzed by LC-ESI-MS. LC separation was performed on a reversed-phase column (Cosmosil 5C $\mathrm{C}_{18}$-AR-II, $\phi 3.0 \times 150 \mathrm{~mm}$ ) with a gradient elution system of $\mathrm{H}_{2} \mathrm{O} / \mathrm{MeCN}$ containing 0.1\% TFA (80:20 to 0:100 for $80 \mathrm{~min}$ ). ESI-MS was performed in a positive ionization mode.

\section{Amino acid analysis}

Amino acid composition was analyzed by AQC method. ${ }^{1}$ Myropeptins (approximately $2 \mathrm{nmol}$ ) and $5 \mathrm{nmol}$ of $n$-valine, an internal standard, were dried in glass vials. The lipopeptides were hydrolyzed with $6 \mathrm{~N} \mathrm{HCl}$ in a gas phase at $110^{\circ} \mathrm{C}$ for $20 \mathrm{~h}$. The hydrolysates were derivatized by 6-aminoquinolyl- $N$-hydroxysuccinimidyl carbamate (Synchem UG \& Co. KG, Felsberg; Germany). Derivatized solutions were analyzed by high-performance liquid chromatography.

\section{Hydrolysis of myropeptins and MS analysis.}

Myropeptins either directly or after hydrolysis with $6 \mathrm{~N} \mathrm{HCl}$ in solution at room temperature for $4 \mathrm{~h}$ were applied to MALDI-TOF MS or nano LC ESI-MS. Intact compounds or hydrolysates were applied to MALDI-TOF MS (ultraflextreme, Bruker daltonics, Bremen, Germany) using $\alpha$-cyano-4-hydroxycinnamic acid as a matrix in the positive mode. Selected peaks were further applied to TOF-TOF analysis. The MS or MS/MS spectra were drawn by FlexAnalysis software (Bruker daltonics).

Intact compounds or hydrolysates were separated on a nanoflow LC (Easy nLC 1000; Thermo Fisher Scientific, Inc.) using a nano-electrospray ionization spray column (NTCC analytical C18 column, $\phi 75 \mu \mathrm{m} \times 100 \mathrm{~mm}, 3 \mu \mathrm{m}$; Nikkyo Technos Co., Ltd., Tokyo, Japan) with a linear gradient of $30-99 \%$ buffer $\mathrm{B}(100 \% \mathrm{MeCN}$ and $0.1 \%$ formic acid) at a flow rate of 300 $\mathrm{nl} / \mathrm{min}$ over $10 \mathrm{~min}$ and subjected on-line to a Q-Exactive mass spectrometer (Thermo Fisher Scientific, Inc.), which was equipped with a nanospray ion source. MS and MS/MS data were acquired using the data-dependent TOP10 method. MS/MS spectra and chromatograms were drawn by Qual Browser (Thermo Fisher Scientific, Inc.).

\section{Synthesis of dodecanoyl-Aib.}

Lauric acid $\left(137.1 \mathrm{mg}, 6.84 \times 10^{-1} \mathrm{mmol}\right)$ was mixed with HBTU $\left(233.3 \mathrm{mg}, 6.15 \times 10^{-1} \mathrm{mmol}\right)$, HOBt $\left(83.1 \mathrm{mg}, 6.15 \times 10^{-1} \mathrm{mmol}\right)$, DIEA $\left(107.1 \mu \mathrm{L}, 6.15 \times 10^{-1} \mathrm{mmol}\right)$ and Aib $\left(63.4 \mathrm{mg}, 6.15 \times 10^{-1}\right.$ mmol) in DMF $(6.83 \mathrm{~mL})$, which was stirred for $5 \mathrm{~h}$ at room temperature. Satd aq $\mathrm{NH}_{4} \mathrm{Cl}$ was added to the reaction mixture. The EtOAc layer was washed three times with satd aq $\mathrm{NH}_{4} \mathrm{Cl}$ and concentrated in vacuo. The obtained residue was chromatographed on an ODS column with a stepwise elution of $\mathrm{H}_{2} \mathrm{O} / \mathrm{MeOH}$ (from 100:0 to 0:100) followed by $\mathrm{CHCl}_{3} / \mathrm{MeOH}$ (1/1). Fractions containing dodecanolyl-AIB was subjected to ODS HPLC on Cosmosil $5 \mathrm{C}_{18}$ AR-II $(\phi 20 \times 250 \mathrm{~mm})$ with $\mathrm{H}_{2} \mathrm{O} / \mathrm{MeCN}(20: 80)$ containing $0.1 \%$ TFA to afford dodecanoly-Aib.

Dodecanoyl-Aib: IR (neat) 3321, 2957, 2916, 1715, 1556, $843 \mathrm{~cm}^{-1} ;{ }^{1} \mathrm{H}$ NMR $\left(\mathrm{CD}_{3} \mathrm{OD}, 500 \mathrm{MHz}\right) \delta 2.16(\mathrm{t}, J=7.5 \mathrm{~Hz}, 2 \mathrm{H}), 1.58(\mathrm{~m}, 2 \mathrm{H}), 1.28-1.36(\mathrm{~m}, 16 \mathrm{H}), 1.45(\mathrm{~s}, 6 \mathrm{H})$, $0.90(\mathrm{t}, J=7.0 \mathrm{~Hz}, 3 \mathrm{H}) ;{ }^{13} \mathrm{C} \mathrm{NMR}\left(\mathrm{CD}_{3} \mathrm{OD}, 125 \mathrm{MHz}\right) \delta 178.1,175.6,56.7,36.8,33.1,30.8$ (2C), 30.7, 30.5 (2C), 30.2, 26.9, 23.7, 14.4; HRMS (ESI) $\mathrm{m} / z 286.2379[\mathrm{M}+\mathrm{H}]^{+}$calcd for $\mathrm{C}_{16} \mathrm{H}_{32} \mathrm{NO}_{3}, 286.2377$.

\section{Synthesis of myropeptin $A_{1}(1)$.}


Bn- $\beta$ Ala (235.1 mg, $\left.6.69 \times 10^{-1} \mathrm{mmol}\right)$ was mixed with HBTU (383.5 mg, $1.01 \mathrm{mmol}$ ), HOBt $(142.9 \mathrm{mg}, 1.06 \mathrm{mmol})$, DIEA $(174.2 \mu \mathrm{L}, 1.00 \mathrm{mmol})$ and Fmoc-L-Ala $\left(249.8 \mathrm{mg}, 8.02 \times 10^{-1}\right.$ $\mathrm{mmol}$ ) in DMF $(6.7 \mathrm{~mL})$, which was stirred for $5 \mathrm{~h}$ at room temperature. Satd aq $\mathrm{NH}_{4} \mathrm{Cl}$ was added to the reaction mixture. The EtOAc layer was washed three times with satd aq $\mathrm{NH}_{4} \mathrm{Cl}$ and concentrated in vacuo. The residue was chromatopraphed $\left(\mathrm{SiO}_{2}, n\right.$-hexane/EtOAc $\left.=1 / 2\right)$ to yield Fmoc-L-Ala- $\beta$ Ala-Bn.

The residue containing Fmoc-L-Ala- $\beta$ Ala-Bn in DMF $(5.36 \mathrm{~mL})$ was stirred, to which piperidine $(1.34 \mathrm{ml})$ was added. After being stirred for $3 \mathrm{~h}$ at room temperature, the reaction mixture was concentrated in vacuo. The residue was washed with $n$-hexane, and then subjected to ODS HPLC on Cosmosil $5 \mathrm{C}_{18}$ PAQ $(\phi 20 \times 250 \mathrm{~mm})$ with $\mathrm{H}_{2} \mathrm{O} / \mathrm{MeOH}$ at $40{ }^{\circ} \mathrm{C}$ to afford L-Ala- $\beta$ Ala-Bn.

L-Ala- $\beta$ Ala-Bn: $[\alpha]_{\mathrm{D}}^{20}-24.7$ (c 0.03, MeOH); IR (neat) 3064, 1672, 1384, 1173, 741 $\mathrm{cm}^{-1} ;{ }^{1} \mathrm{H}$ NMR $\left(\mathrm{CD}_{3} \mathrm{OD}, 500 \mathrm{MHz}\right) \delta 7.73(\mathrm{NH}), 7.68(\mathrm{NH}), 7.28-7.36(5 \mathrm{H}), 5.13(\mathrm{~d}, J=3.0 \mathrm{~Hz}$, $2 \mathrm{H}), 3.84(\mathrm{q}, J=7.0 \mathrm{~Hz}, 1 \mathrm{H}), 3.50(\mathrm{~m}, 2 \mathrm{H}), 2.61(\mathrm{~m}, 2 \mathrm{H}), 1.41(\mathrm{~d}, J=7.5 \mathrm{~Hz}, 3 \mathrm{H}) ;{ }^{13} \mathrm{C} \mathrm{NMR}$ $\left(\mathrm{CD}_{3} \mathrm{OD}, 125 \mathrm{MHz}\right) \delta 172.9,171.1,129.5,129.3,126.2,125.9,118.7,112.1,67.5,50.1,36.5$, 34.6, 17.6; HRMS (ESI) $m / z 251.1387[\mathrm{M}+\mathrm{H}]^{+}$calcd for $\mathrm{C}_{13} \mathrm{H}_{19} \mathrm{~N}_{2} \mathrm{O}_{3}, 251.1390$.

L-Ala-BAla-Bn $\left(13.20 \mathrm{mg}, 5.28 \times 10^{-2} \mathrm{mmol}\right)$ was mixed with Oxyma $\left(13.4 \mathrm{mg}, 9.42 \times 10^{-2}\right.$ mmol), COMU (27.3 mg, $\left.6.38 \times 10^{-2} \mathrm{mmol}\right)$, DIEA $\left(10.0 \mu \mathrm{L}, 5.72 \times 10^{-2} \mathrm{mmol}\right)$ and myropeptin B $\left(3,9.8 \mathrm{mg}, 5.72 \times 10^{-3} \mathrm{mmol}\right)$ in DMF $(1.0 \mathrm{~mL})$, which was stirred for $16.5 \mathrm{~h}$ at $70{ }^{\circ} \mathrm{C}$. Satd aq $\mathrm{NH}_{4} \mathrm{Cl}$ was added to the reaction mixture. The organic layer was washed three times with satd aq $\mathrm{NH}_{4} \mathrm{Cl}$ and concentrated in vacuo. The residue was subjected to ODS HPLC on Cosmosil $5 \mathrm{C}_{18}$ AR-II $(\phi 10 \times 250 \mathrm{~mm})$ with $\mathrm{H}_{2} \mathrm{O} / \mathrm{MeCN}$ at $40{ }^{\circ} \mathrm{C}$ to afford $\mathrm{Bn}$ - myropeptin $\mathrm{A}_{1}$.

Bn- myropeptin $\mathrm{A}_{1}$ in $\mathrm{MeOH}(200 \mu \mathrm{L})$ was stirred with $10 \% \mathrm{Pd} / \mathrm{C}$ in a hydrogen atomosphere for $15 \mathrm{~h}$. After concentration in vacuo, the reaction mixture was suspended in $\mathrm{H}_{2} \mathrm{O}$ and extracted three times with EtOAc. The organic layer was concentrated in vacuo to yield myropeptin $\mathrm{A}_{1}(\mathbf{1}$, $0.17 \mathrm{mg}$ ): HRMS (ESI) $m / z$ 1876.1296 [M+Na] $]^{+}$calcd for $\mathrm{C}_{89} \mathrm{H}_{152} \mathrm{~N}_{20} \mathrm{NaO}_{22}, 1876.1282$.

\section{Hemolytic activity.}

Sheep erythrocytes were prepared by washing sheep whole blood (Kohjin Bio Co., Ltd. Japan) with buffer [10 mM phosphate buffer ( $\mathrm{pH}$ 7.4) containing $150 \mathrm{mM} \mathrm{NaCl}]$. Rabbit erythrocytes $\left(4 \times 10^{7}\right.$ cells $\left./ \mathrm{ml}, 100 \mu \mathrm{L}\right)$ were mixed with $100 \mu \mathrm{L}$ of PBS buffer containing myropeptins or $0.1 \%$ Triton $\mathrm{X}-100$, which were incubated for $30 \mathrm{~min}$ at $37^{\circ} \mathrm{C}$. After centrifugation at $2400 \mathrm{rpm}$ for $10 \mathrm{~min}, 160 \mu \mathrm{l}$ of the supernatants were moved to another plate, and the absorbance at $\mathrm{OD}_{450}$ was measured using iMark microplate reader (BIO-RAD).

\section{Antifungal activity.}

Antifungal effect of compounds was assessed using wild-type fission yeast cells (Schizosaccharomyces. pombe, JY1, $h^{-}$), as reported previously with some minor changes. ${ }^{2}$ Briefly, cells were cultured in EMME medium. This medium is EMM but $\mathrm{NH}_{4} \mathrm{Cl}$ was replaced by Glu. ${ }^{3}$ Cells were exposed to screening samples or purified compounds dissolved in DMSO $(1 \% \mathrm{v} / \mathrm{v})$ at $30{ }^{\circ} \mathrm{C}$ for $72 \mathrm{~h}$. After incubation, the turbidity was measured at $\mathrm{OD}_{595}$ using iMark microplate reader (BIO-RAD). 
Supplementary Table S1. NMR data of myropeptin B (3) in DMSO- $d_{6}$

\begin{tabular}{|c|c|c|c|c|c|}
\hline residue & ${ }^{13} \mathrm{C}$ & ${ }^{1} \mathrm{H}$ (mult., $J$ in $\mathrm{Hz}$ ) & residue & ${ }^{13} \mathrm{C}$ & ${ }^{1} \mathrm{H}$ (mult., $J$ in $\mathrm{Hz}$ ) \\
\hline dodecanoly $\mathrm{C}=\mathrm{O}$ & 172.9 & & Aib-10 & 174.1 & \\
\hline 2 & $22.1-31.3$ & 2.20 & 1 & $56.2-55.6$ & \\
\hline 3-11 & $22.1-31.3$ & $1.17-1.51$ & 2 & $22.1-31.3$ & $1.17-1.51$ \\
\hline 12 & 14.2 & $0.82(t)$ & 3 & $22.1-31.3$ & $1.17-1.51$ \\
\hline Aib-1 & $172.6-176.0$ & & $\mathrm{NH}$ & & 7.33 (s) \\
\hline 1 & $56.2-55.6$ & & BAla-11 $\quad \mathrm{C}=\mathrm{O}$ & 171.1 & \\
\hline 2 & $22.1-31.3$ & $1.17-1.51$ & 1 & 35.1 & 2.28 \\
\hline 3 & $22.1-31.3$ & $1.17-1.51$ & 2 & 35.7 & 3.20 \\
\hline $\mathrm{NH}$ & & $8.58(\mathrm{~s})$ & $\mathrm{NH}$ & & $7.08(\mathrm{dd}, 11.1)$ \\
\hline Pro-2 & 171.9 & & Ala-12 & $173.6-173.7$ & \\
\hline 1 & 63.3 & $4.10(\mathrm{dd}, 8.0)$ & 1 & 49.6 & 4.02 \\
\hline 2 & $22.1-31.3$ & $1.70,2.17$ & 2 & 16.8 & 1.20 \\
\hline 3 & $22.1-31.3$ & 1.81 & $\mathrm{NH}$ & & $8.20(\mathrm{~d}, 9.2)$ \\
\hline 4 & $48.0-48.2$ & $3.26,3.73$ & Aib-13 & 173.2-173.4 & \\
\hline Aib-3 & $172.6-176.0$ & & 1 & $56.2-55.6$ & \\
\hline 1 & $56.2-55.6$ & & 2 & $22.1-31.3$ & $1.17-1.51$ \\
\hline 2 & $22.1-31.3$ & $1.17-1.51$ & 3 & $22.1-31.3$ & $1.17-1.51$ \\
\hline 3 & $22.1-31.3$ & $1.17-1.51$ & $\mathrm{NH}$ & & $8.44(\mathrm{~s})$ \\
\hline $\mathrm{NH}$ & & $7.56(\mathrm{~s})$ & Aib-14 & 174.6 & \\
\hline Aib-4 & $172.6-176.0$ & & 1 & $56.2-55.6$ & \\
\hline 1 & $56.2-55.6$ & & 2 & $22.1-31.3$ & $1.17-1.51$ \\
\hline 2 & $22.1-31.3$ & $1.17-1.51$ & 3 & $22.1-31.3$ & $1.17-1.51$ \\
\hline 3 & $22.1-31.3$ & $1.17-1.51$ & $\mathrm{NH}$ & & $7.25(\mathrm{~s})$ \\
\hline $\mathrm{NH}$ & & 7.75 (s) & BAla-15 & 171.3 & \\
\hline Pro-5 & 171.9 & & 1 & 36.5 & 2.28 \\
\hline 1 & 63.1 & $4.10(\mathrm{dd}, 8.0)$ & 2 & 35.5 & 3.26 \\
\hline 2 & $22.1-31.3$ & $1.60,2.16$ & $\mathrm{NH}$ & & $7.38(\mathrm{dd}, 6.0)$ \\
\hline 3 & $22.1-31.3$ & 1.80 & Aib-16 & 173.0 & \\
\hline 4 & $48.0-48.2$ & 3.65 & 1 & $56.2-55.6$ & \\
\hline $\mathrm{C}=\mathrm{O}$ & $172.6-176.0$ & & 2 & $22.1-31.3$ & $1.17-1.51$ \\
\hline 1 & $56.2-55.6$ & & 3 & $22.1-31.3$ & $1.17-1.51$ \\
\hline 2 & 22.1-31.3 & $1.17-1.51$ & $\mathrm{NH}$ & & $8.05(\mathrm{~s})$ \\
\hline 3 & $22.1-31.3$ & $1.17-1.51$ & Aib-17 & $172.6-176.0$ & \\
\hline $\mathrm{NH}$ & & $7.56(\mathrm{~s})$ & 1 & 54.7 & \\
\hline $\mathrm{C}=\mathrm{O}$ & $172.6-176.0$ & & 2 & $22.1-31.3$ & $1.17-1.51$ \\
\hline 1 & $56.2-55.6$ & & 3 & $22.1-31.3$ & $1.17-1.51$ \\
\hline 2 & $22.1-31.3$ & $1.17-1.51$ & $\mathrm{NH}$ & & $7.44(\mathrm{~s})$ \\
\hline 3 & $22.1-31.3$ & $1.17-1.51$ & Aib-18 & $172.6-176.0$ & \\
\hline $\mathrm{NH}$ & & $7.82(\mathrm{~s})$ & 1 & $56.2-55.6$ & \\
\hline Pro-8 & 172.2 & & 2 & $22.1-31.3$ & $1.17-1.51$ \\
\hline 1 & 62.5 & $4.26(\mathrm{dd}, 6.5,9.0)$ & 3 & $22.1-31.3$ & $1.17-1.51$ \\
\hline 2 & $22.1-31.3$ & $1.68,2.15$ & $\mathrm{NH}$ & & $7.70(\mathrm{~s})$ \\
\hline 3 & 22.1-31.3 & 1.81 & & & \\
\hline 4 & $48.0-48.2$ & $3.60,3.79$ & & & \\
\hline $\mathrm{C}=\mathrm{O}$ & 171.9 & & & & \\
\hline 1 & 49.4 & 4.05 & & & \\
\hline $2^{t}$ & 16.8 & 1.29 & & & \\
\hline $\mathrm{NH}$ & & $7.78(\mathrm{~d}, 7.9)$ & & & \\
\hline
\end{tabular}




\section{Supplementary figures}

(a)

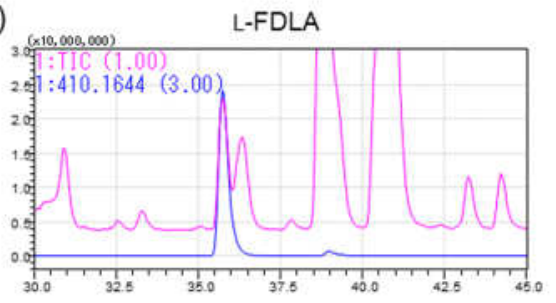

(b)

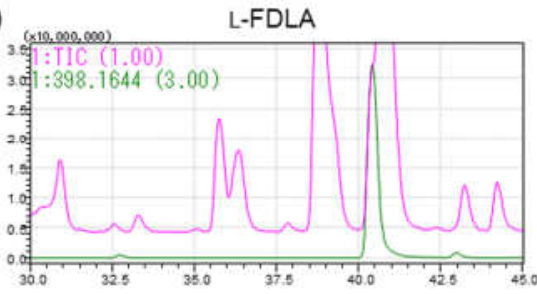

(c)

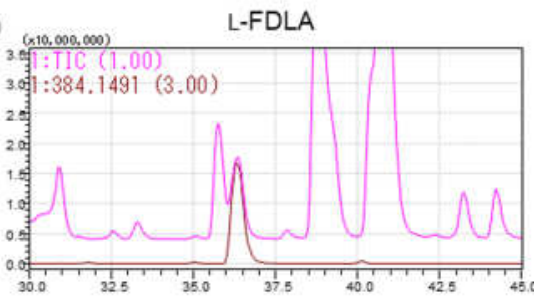

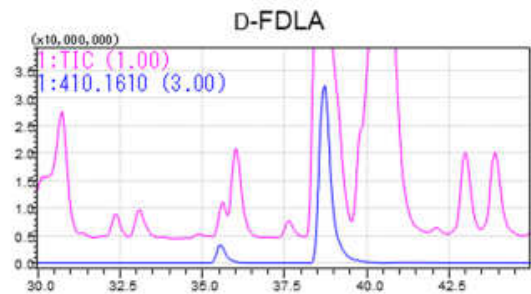
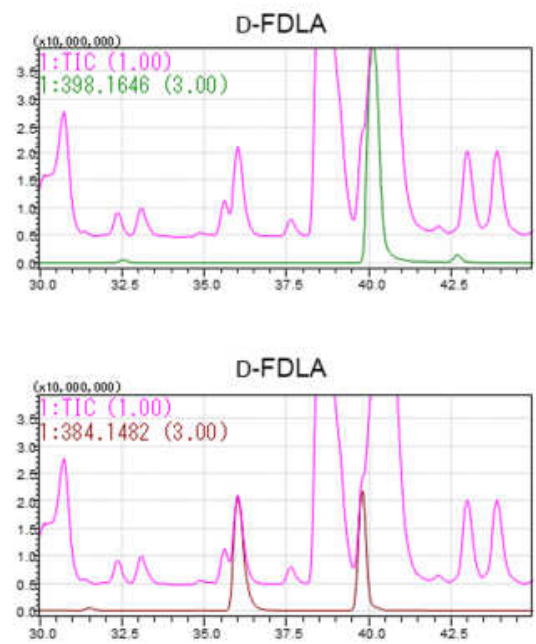

Figure S1. LC-MS analysis of FDLA derivatives of amino acids derived from myropeptin B (3). MS chromatograms for Pro (a), Aib (b), and Ala and $\beta$-Ala (c) are shown. The elution pattern deduced the chirality of amino acids as L for both Pro and Ala. 

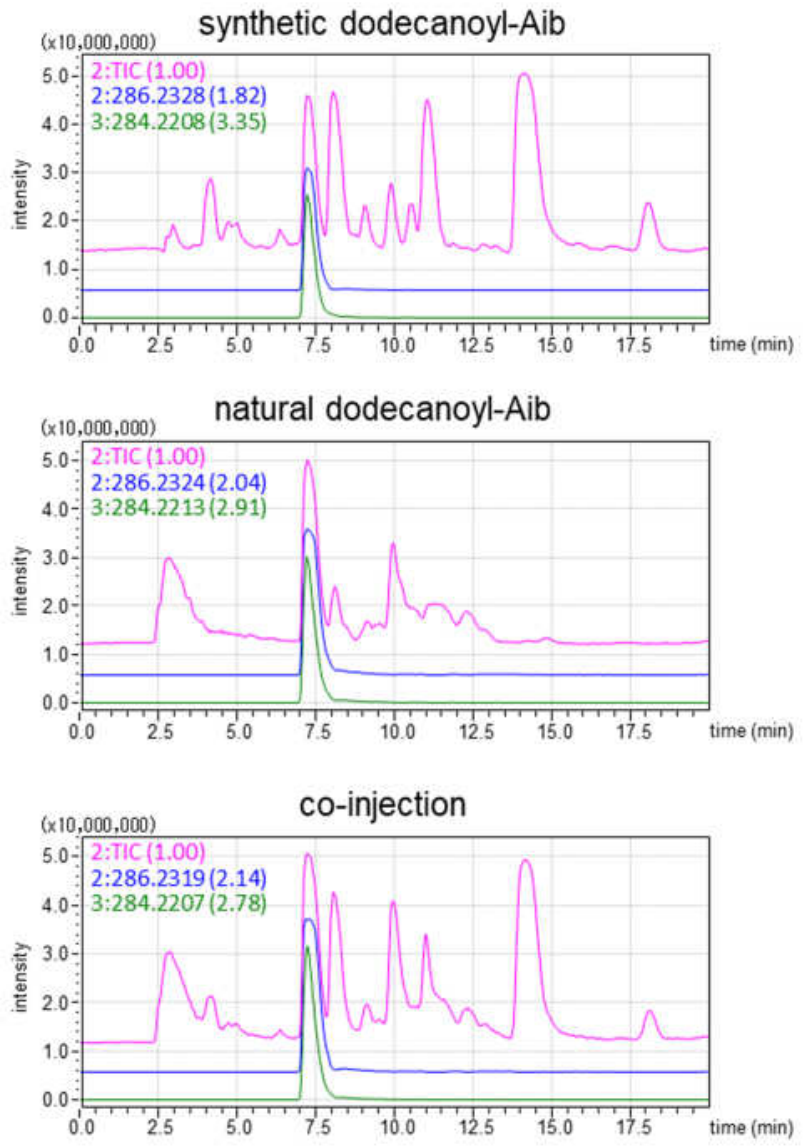

Figure S2. Detection of dodecanoyl Aib from myropeptin B (3). 


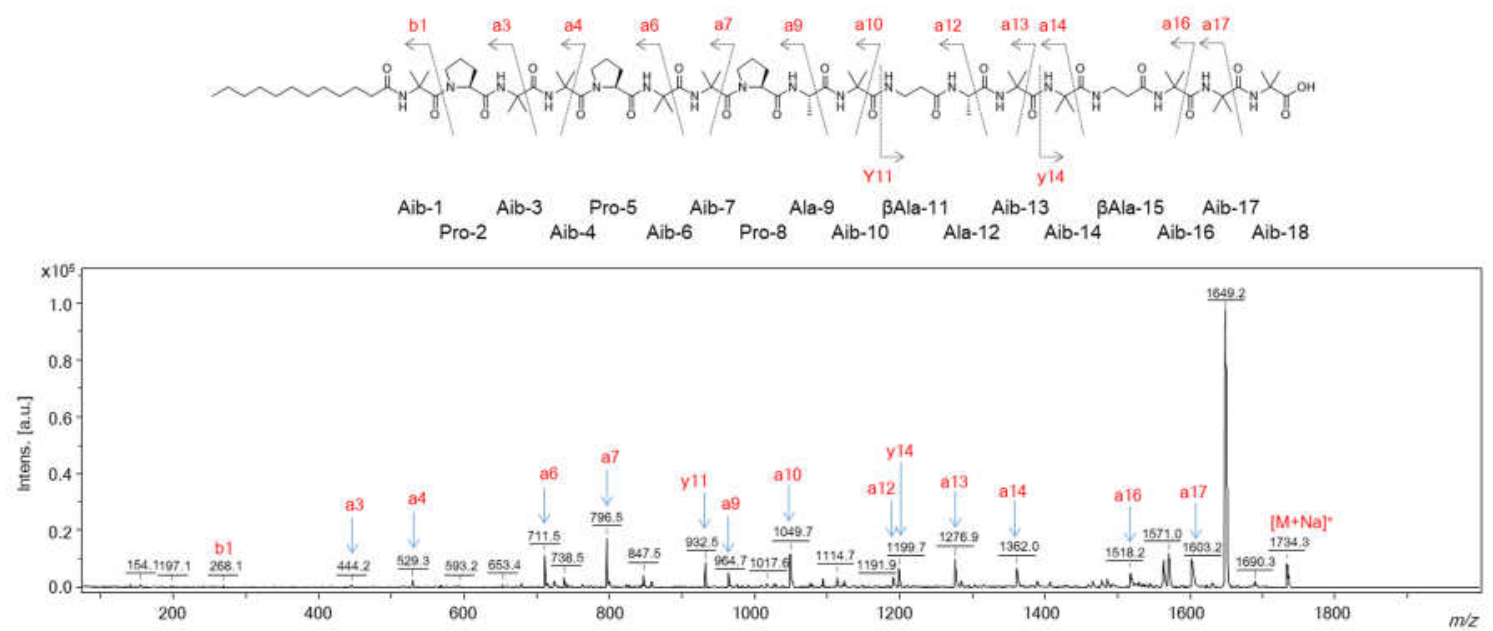

Figure S3. MALDI-TOF MS/MS analysis of the intact myropeptin B (3). An ion peak of $[\mathrm{M}+\mathrm{Na}]^{+}$at $\mathrm{m} / \mathrm{z} 1734.3$ was chosen as a precursor peak. Fragment peaks except for b1 ion was detected as $\mathrm{Na}^{+}$adduct. 


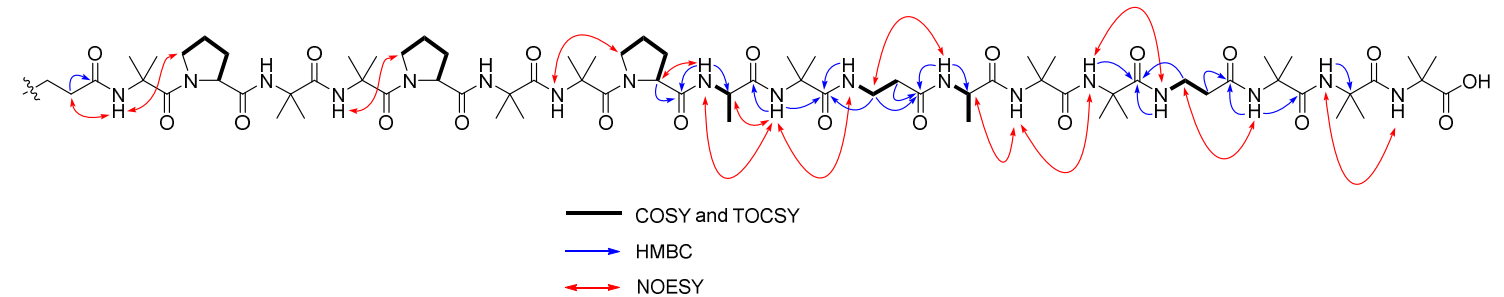

Figure S4. Key NMR correlations in myropeptin B (3). 


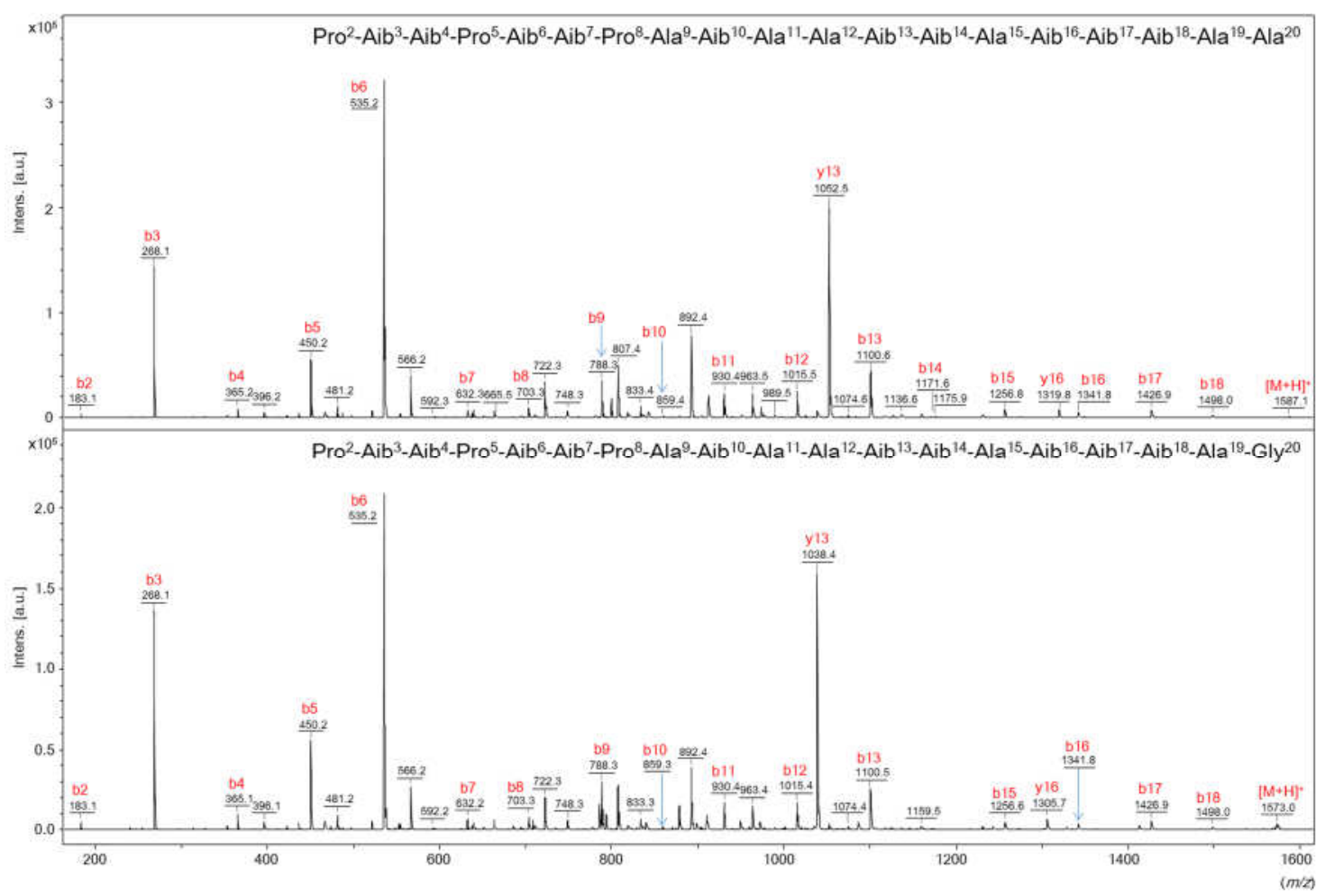

Figure S5. MALDI-TOF MS/MS analysis of myropeptin $A_{1}(1)$ and $A_{2}$ (2). After hydrolysis of the myropeptin A mixture in aqueous $6 \mathrm{~N} \mathrm{HCl}$, ion peaks corresponding to peptides lacking the C-terminal dodecanoyl-Aib were chosen as precursor ions. MS/MS spectra of myropeptin $A_{1}(\mathbf{1})$ (upper panel) and myropeptin $\mathrm{A}_{2}$ (2) (lower panel) are shown. 


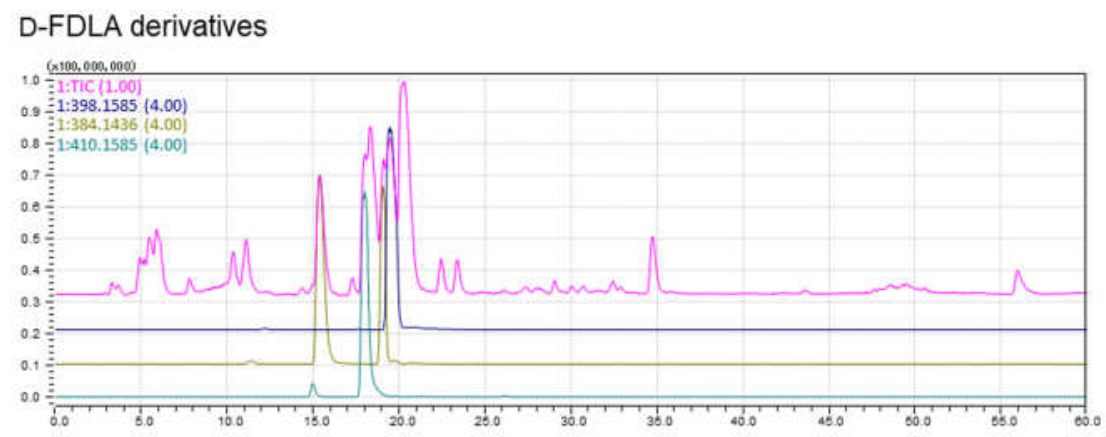

L-FDLA derivatives

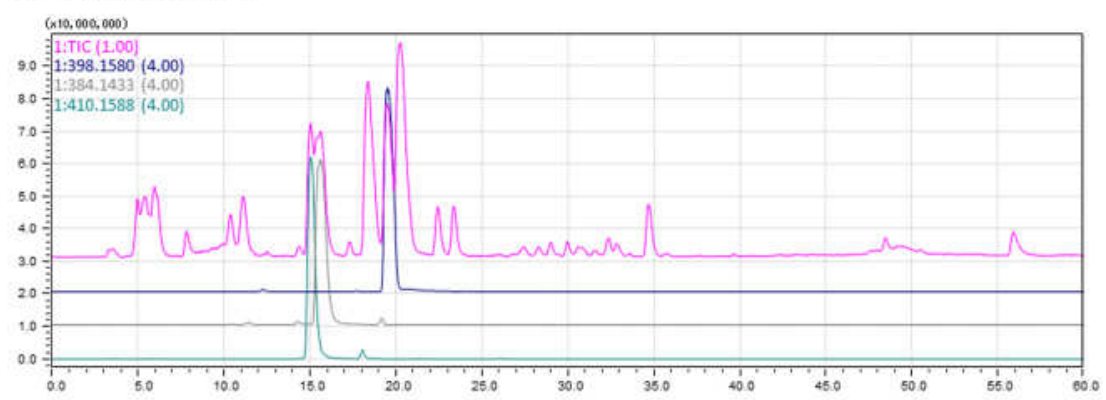

Figure S6. LC-MS analysis of FDLA derivatives of amino acids derived from natural myropeptin A (1,2). MS chromatograms for Aib $(\mathrm{m} / \mathrm{z} 398.15)$, Ala and $\beta$-Ala $(\mathrm{m} / \mathrm{z}, 384.14)$, and Pro $(\mathrm{m} / \mathrm{z}$ 410.16) are shown. The elution pattern deduced the chirality of amino acids as L for both Pro and Ala. 


\section{References for supplementary information}

(1) Masuda, A.; Dohmae, N. Biosci. Trends 2011, 5, 231.

(2) Nishimura, S.; Arita, Y.; Honda, M.; Iwamoto, K.; Matsuyama, A.; Shirai, A.; Kawasaki, H.; Kakeya, H.; Kobayashi, T.; Matsunaga, S.; Yoshida, M. Nat. Chem. Biol. $2010,6,519$.

(3) Sabatinos, S. A.; Forsburg, S. L. Methods Enzymol. 2010, 470, 759. 
${ }^{1} \mathrm{H}$ NMR spectrum of myropeptin $\mathrm{A}(1,2)$ in $\mathrm{CD}_{3} \mathrm{OH}(500 \mathrm{MHz})$.

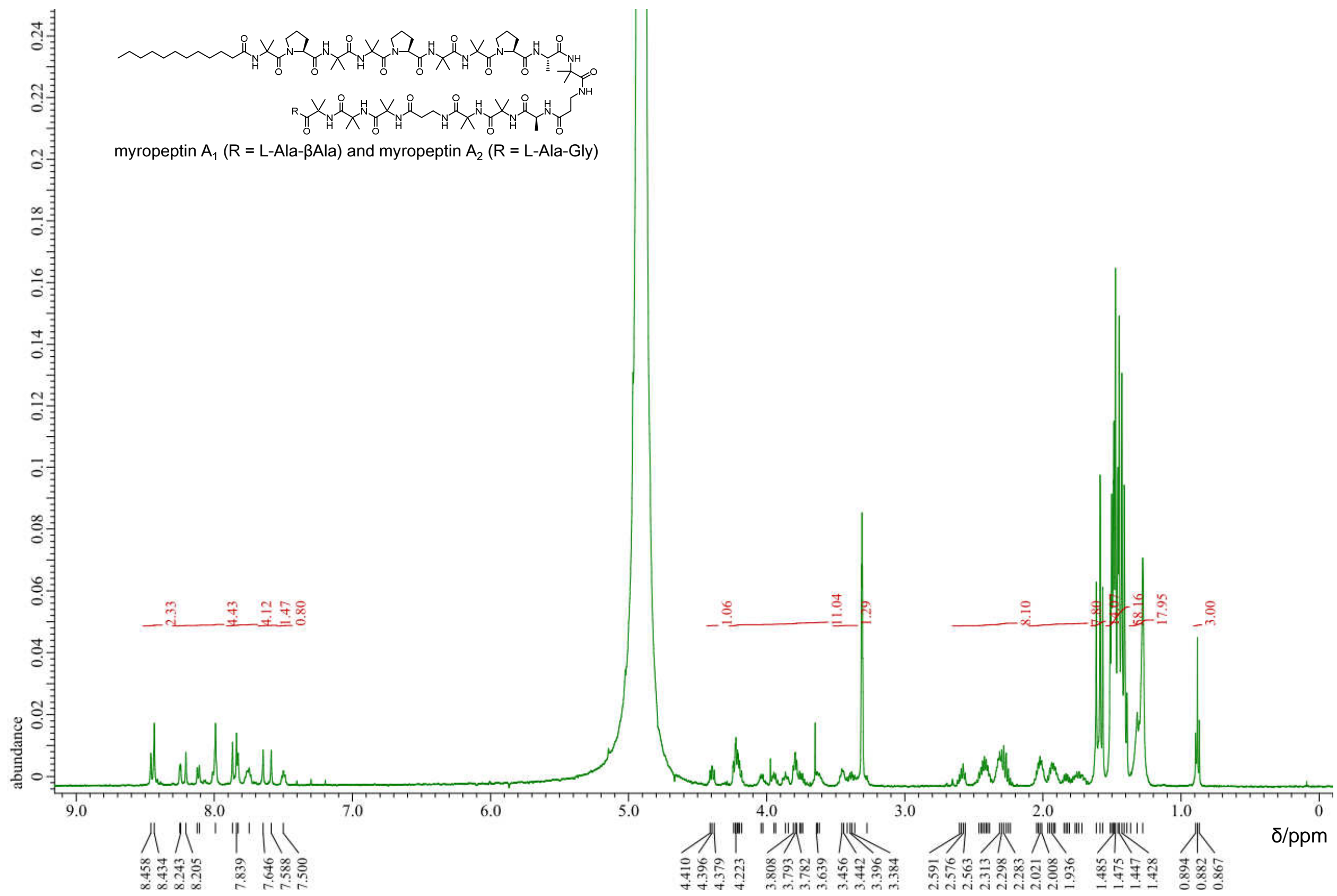


${ }^{13} \mathrm{C}$ NMR spectrum of myropeptin $\mathrm{A}(1,2)$ in $\mathrm{CD}_{3} \mathrm{OH}(125 \mathrm{MHz})$.

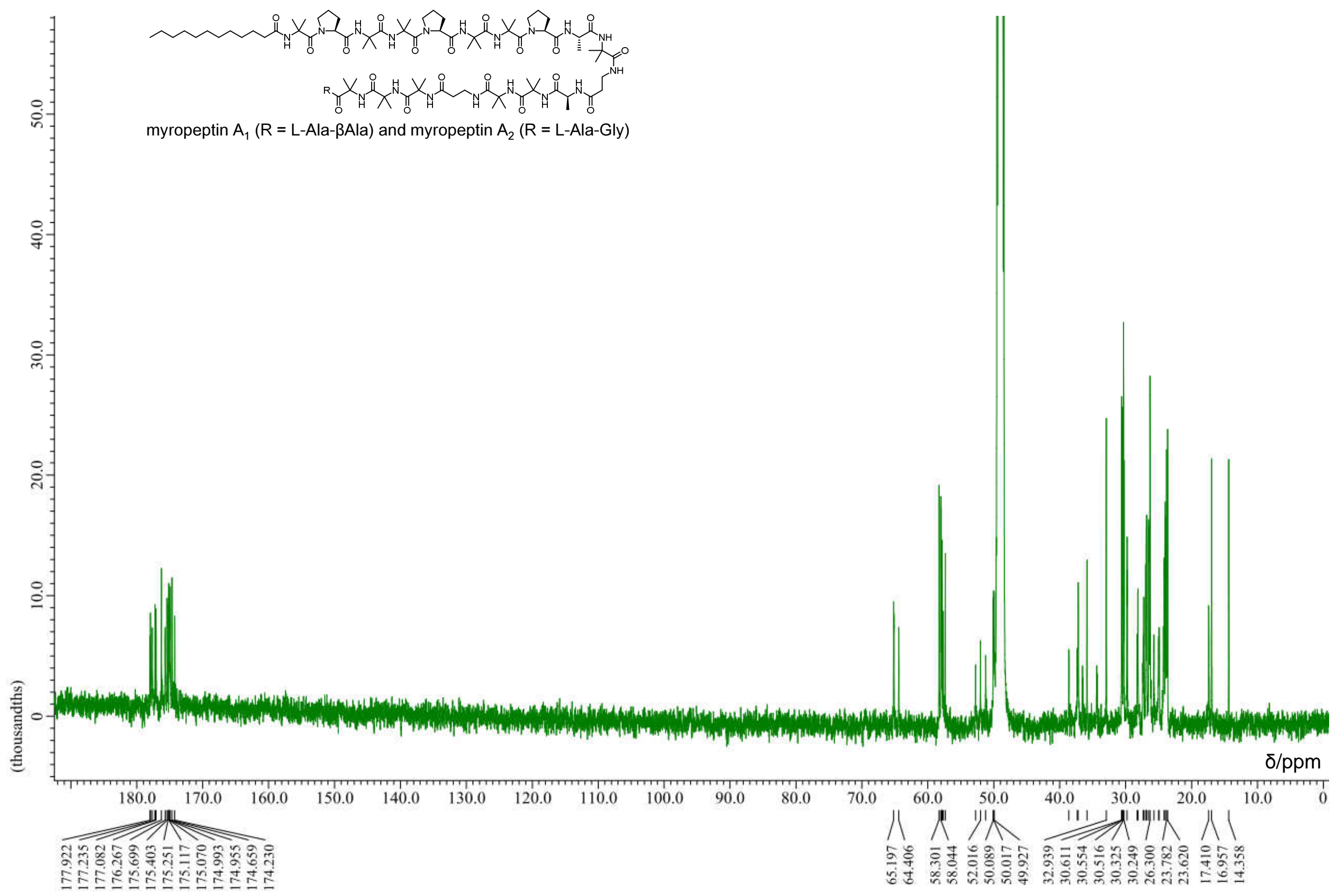


${ }^{1} \mathrm{H}$ NMR spectrum of myropeptin $\mathrm{A}(1,2)$ in DMSO- $d_{6}(500 \mathrm{MHz})$.

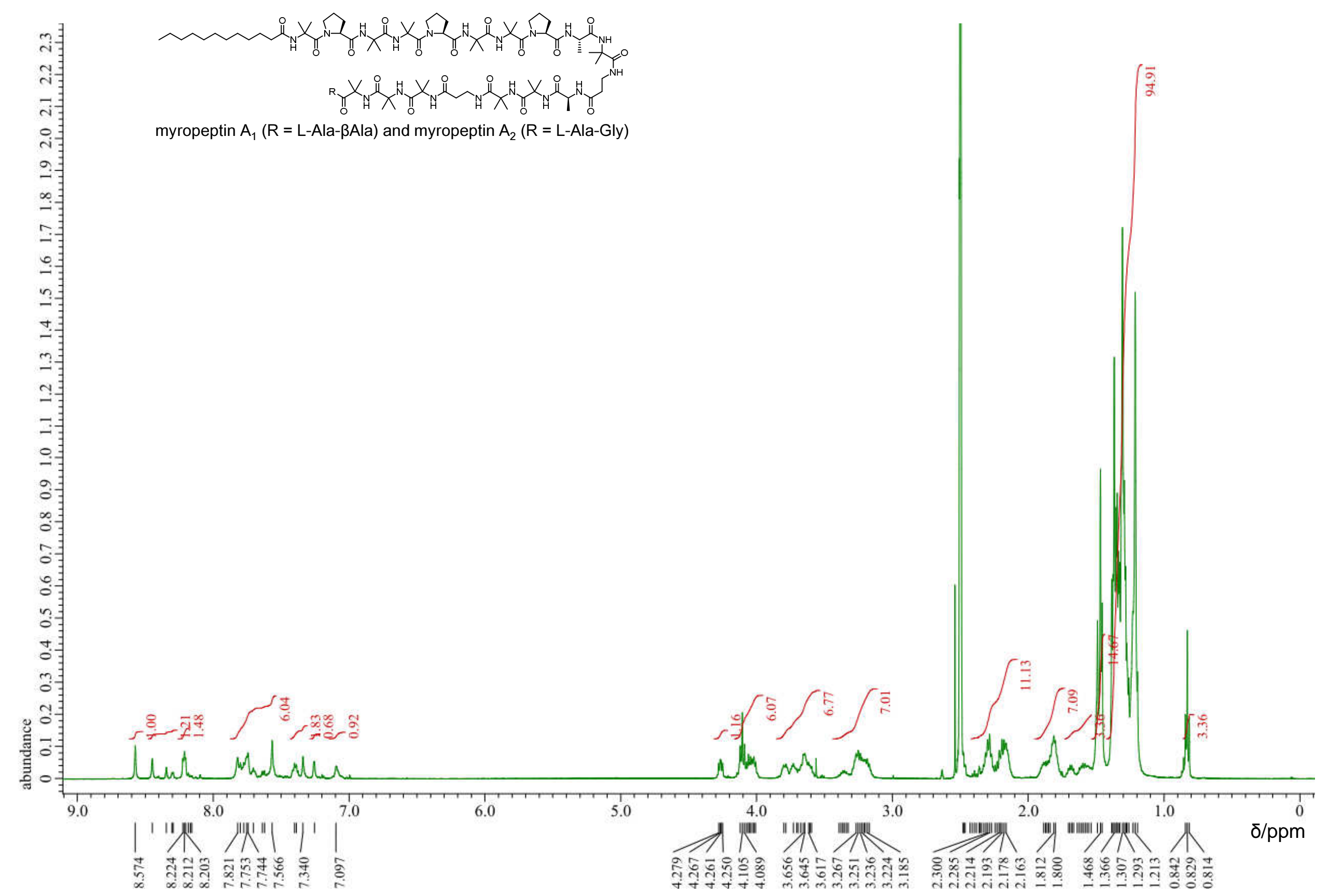


${ }^{13} \mathrm{C}$ NMR spectrum of myropeptin $\mathrm{A}(1,2)$ in DMSO- $d_{6}(125 \mathrm{MHz})$.

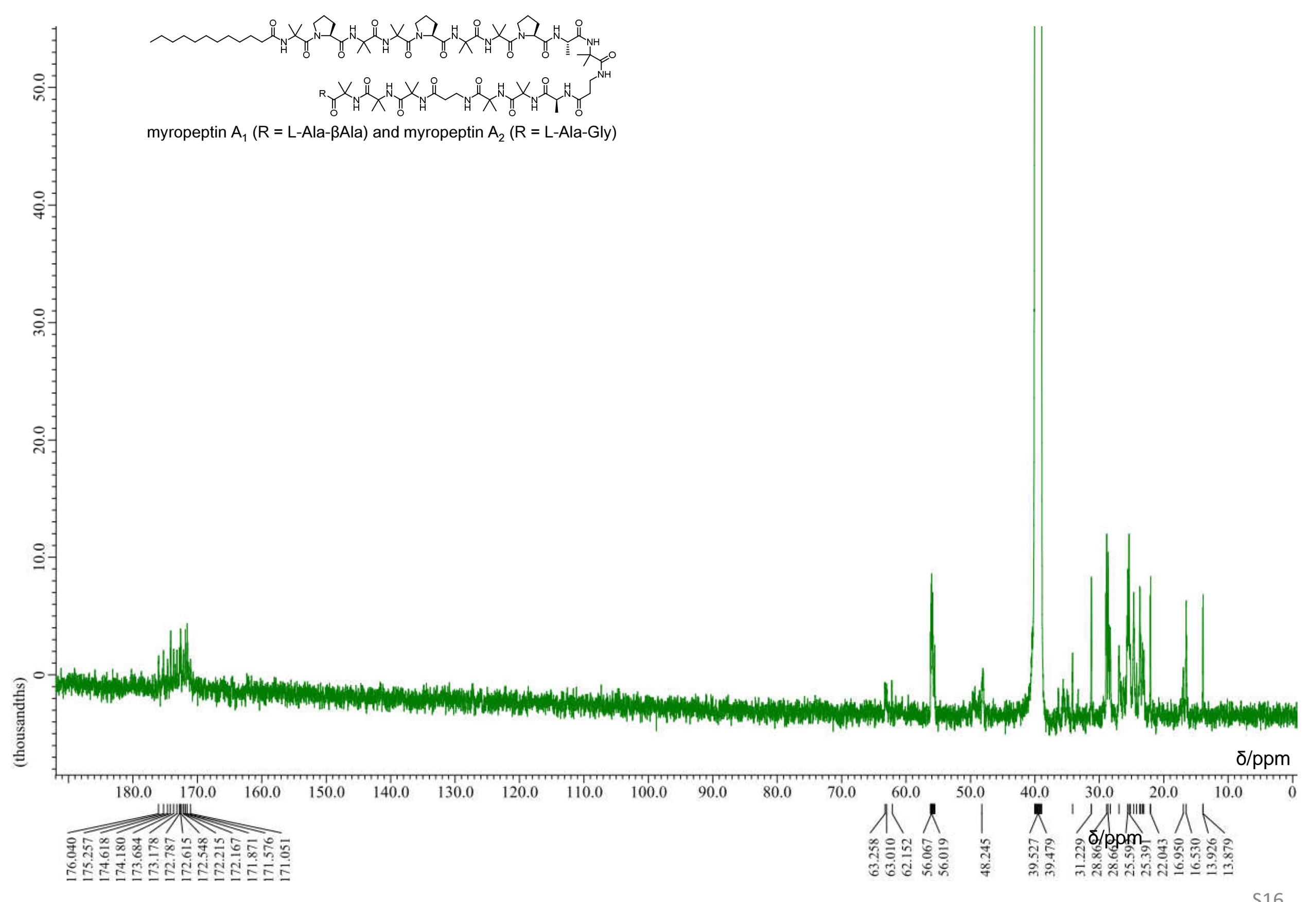


${ }^{1} \mathrm{H}$ NMR spectrum of myropeptin B (3) in DMSO- $d_{6}(500 \mathrm{MHz})$.

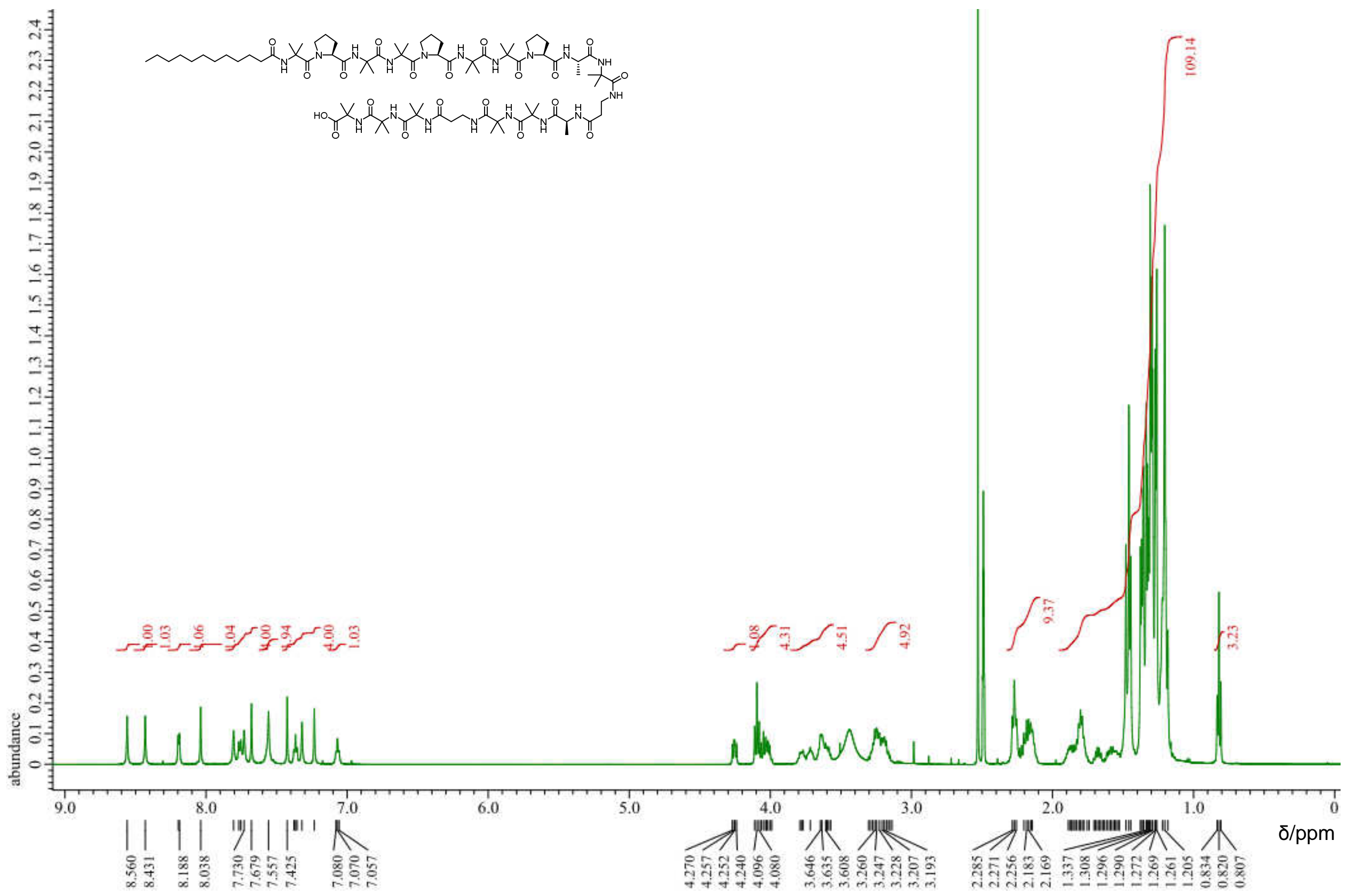


${ }^{13} \mathrm{C}$ NMR spectrum of myropeptin B (3) in DMSO- $d_{6}(125 \mathrm{MHz})$.

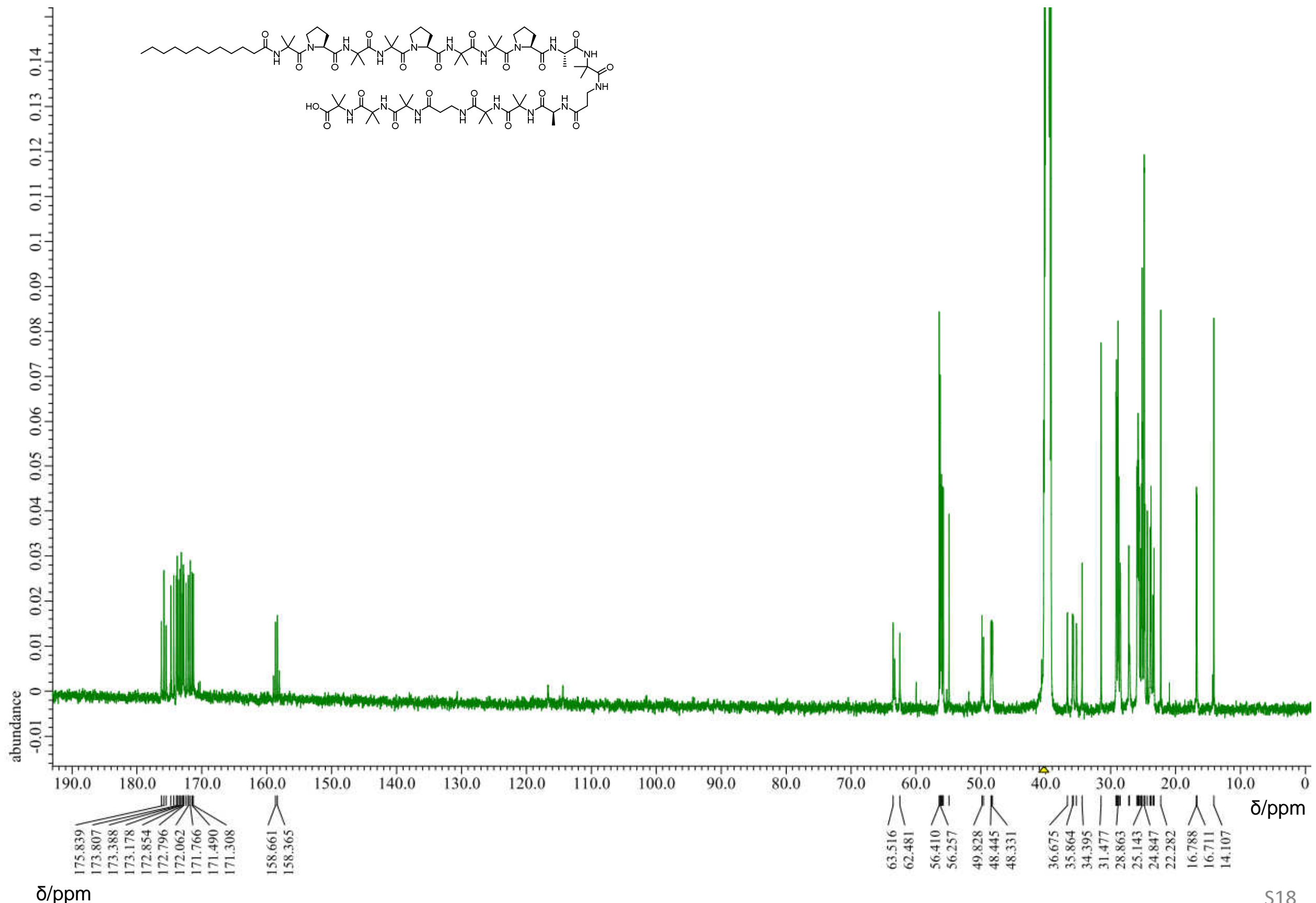


COSY spectrum of myropeptin B (3) in DMSO- $d_{6}(500 \mathrm{MHz})$.

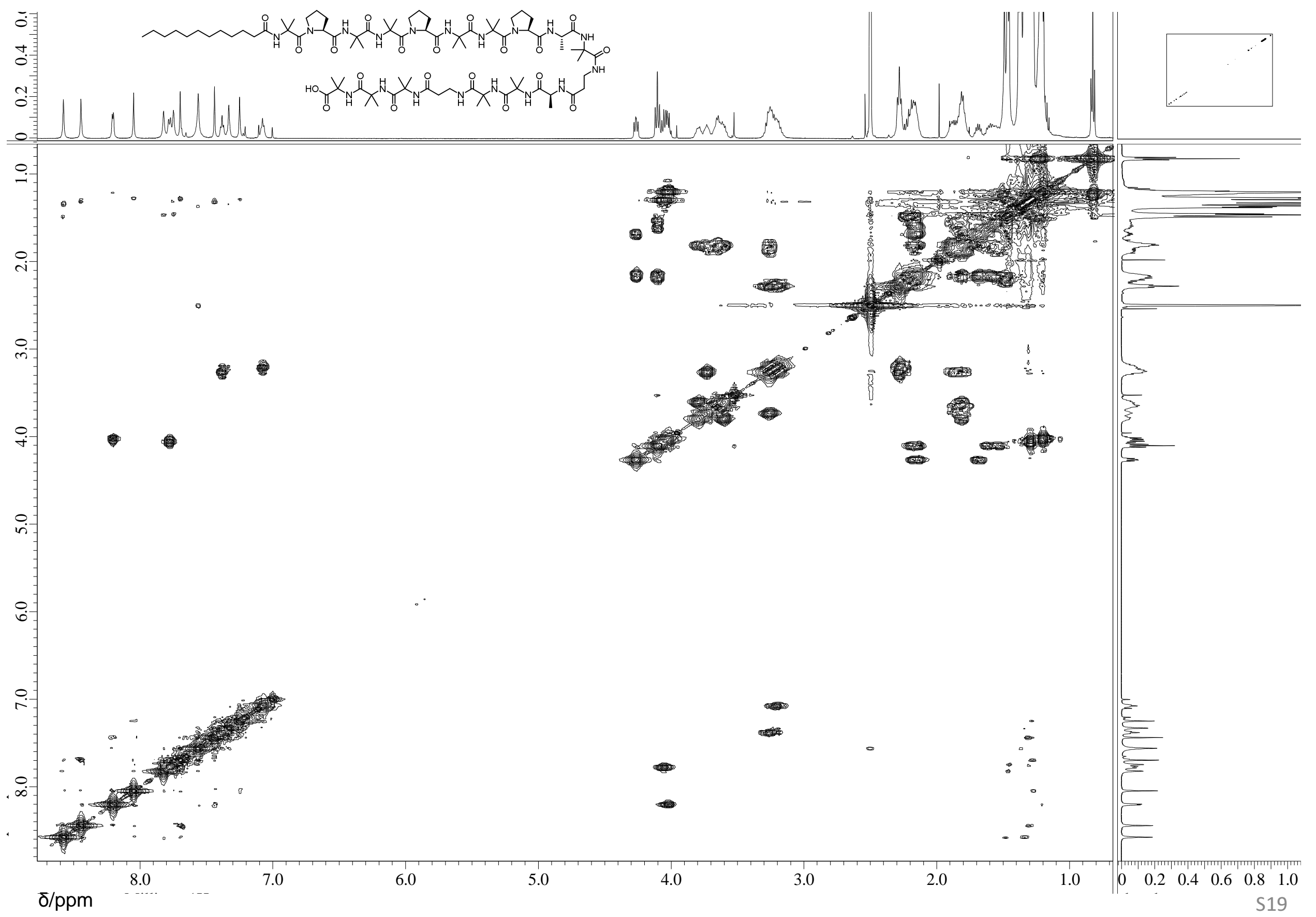


TOCSY spectrum of myropeptin B (3) in DMSO- $d_{6}(500 \mathrm{MHz})$.

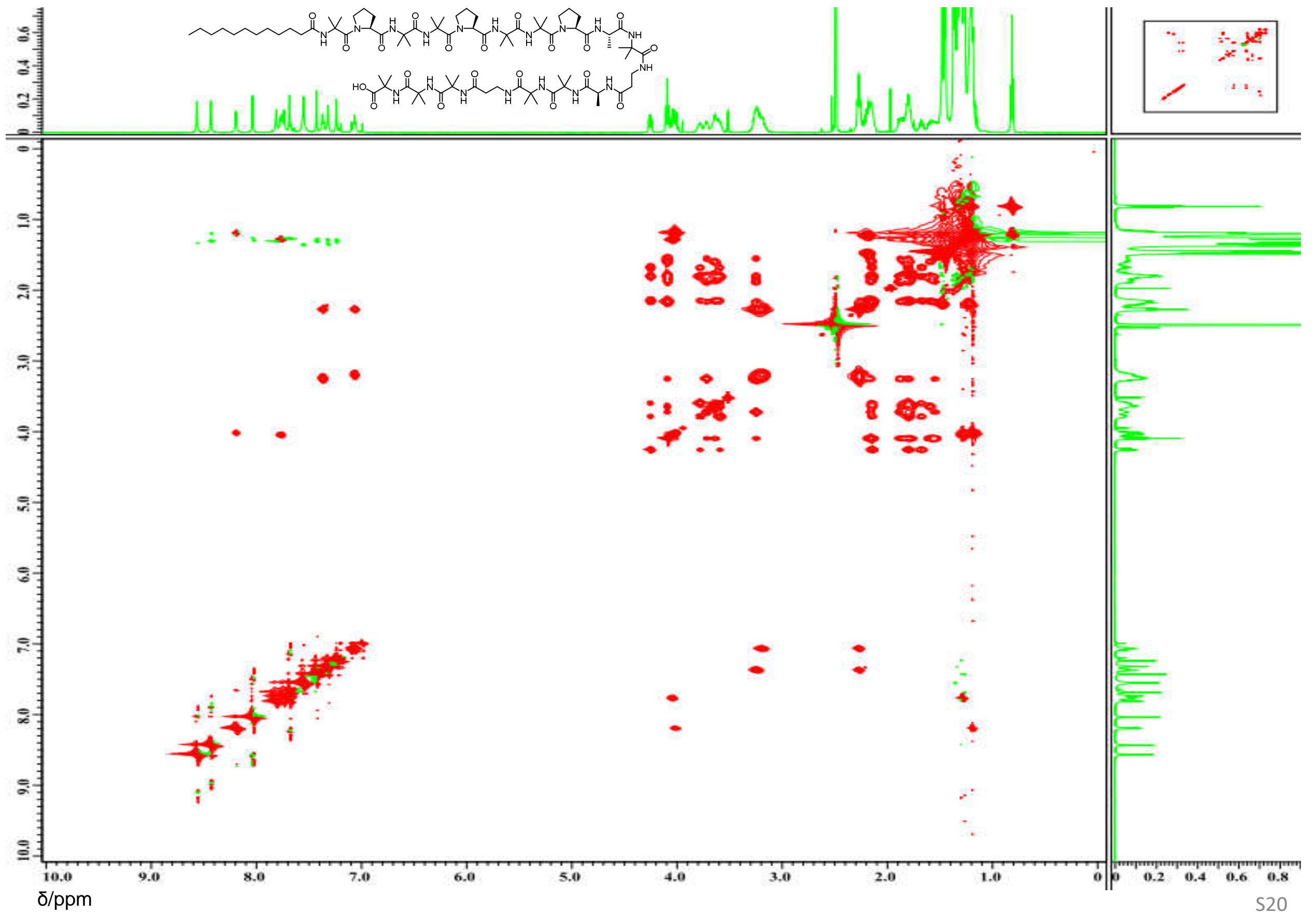


HMQC spectrum of myropeptin B (3) in DMSO- $d_{6}(500 \mathrm{MHz})$.

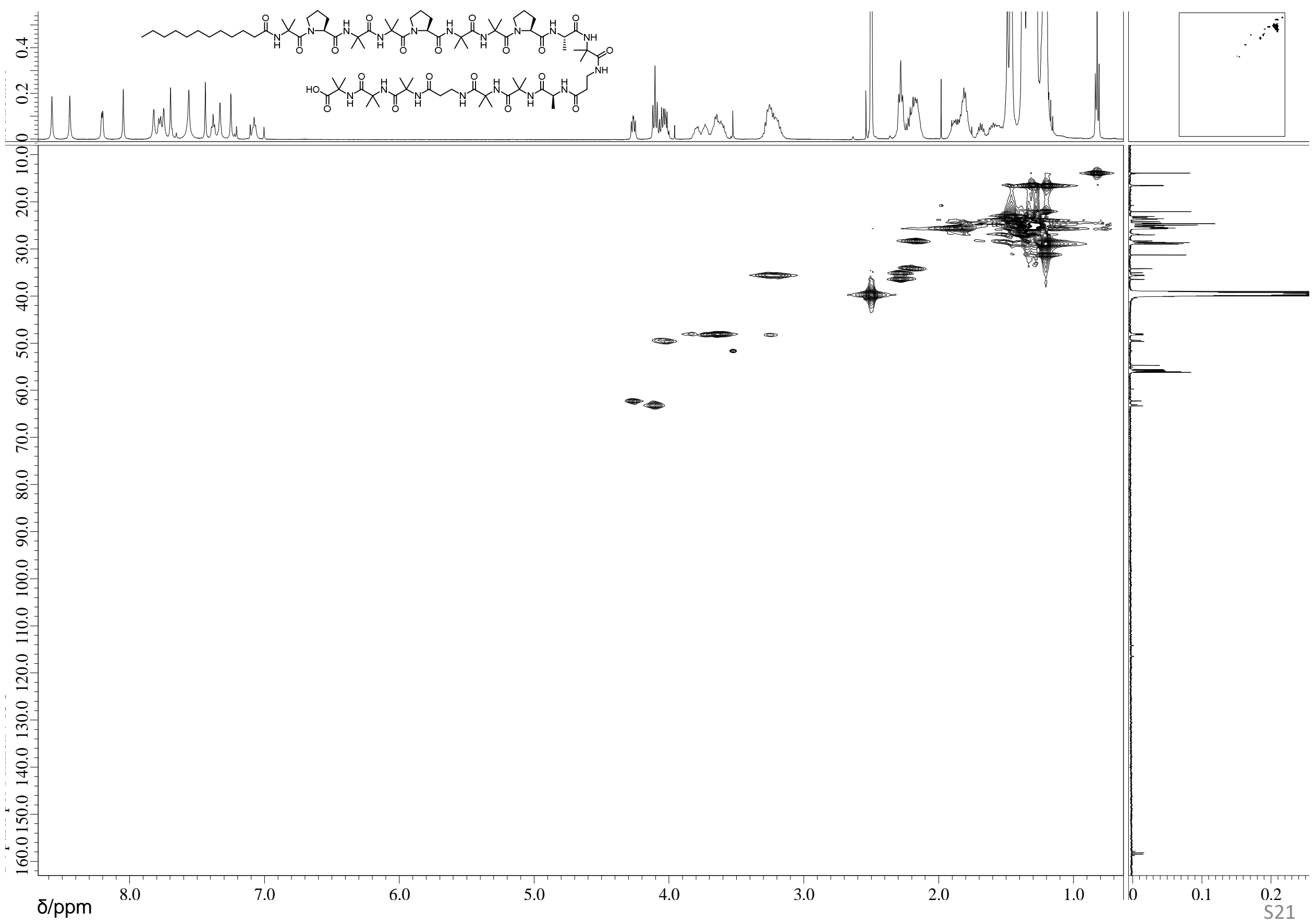


HMBC spectrum of myropeptin B (3) in DMSO- $d_{6}(500 \mathrm{MHz})$.

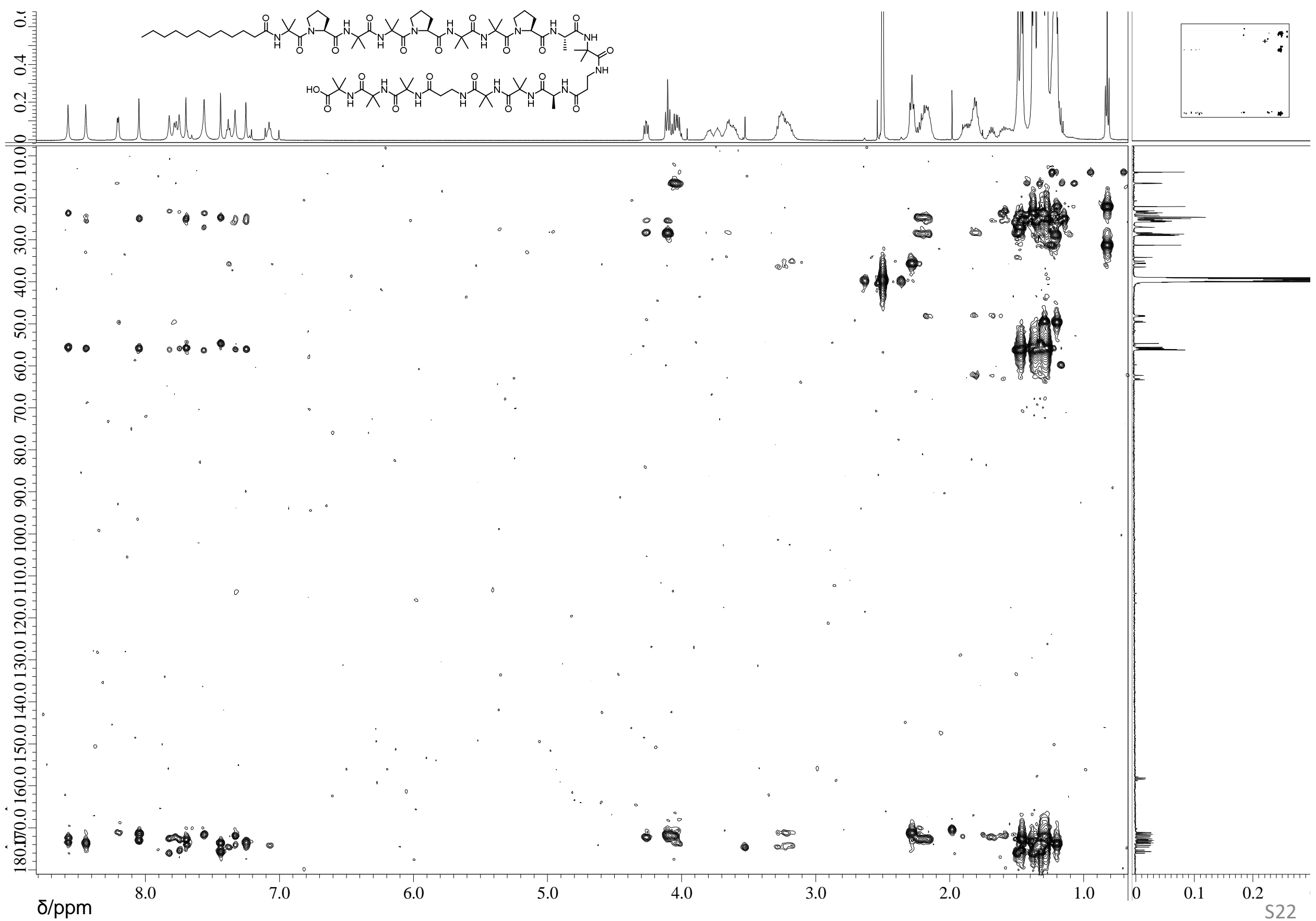


NOESY spectrum of myropeptin B (3) in DMSO- $d_{6}(500 \mathrm{MHz})$.

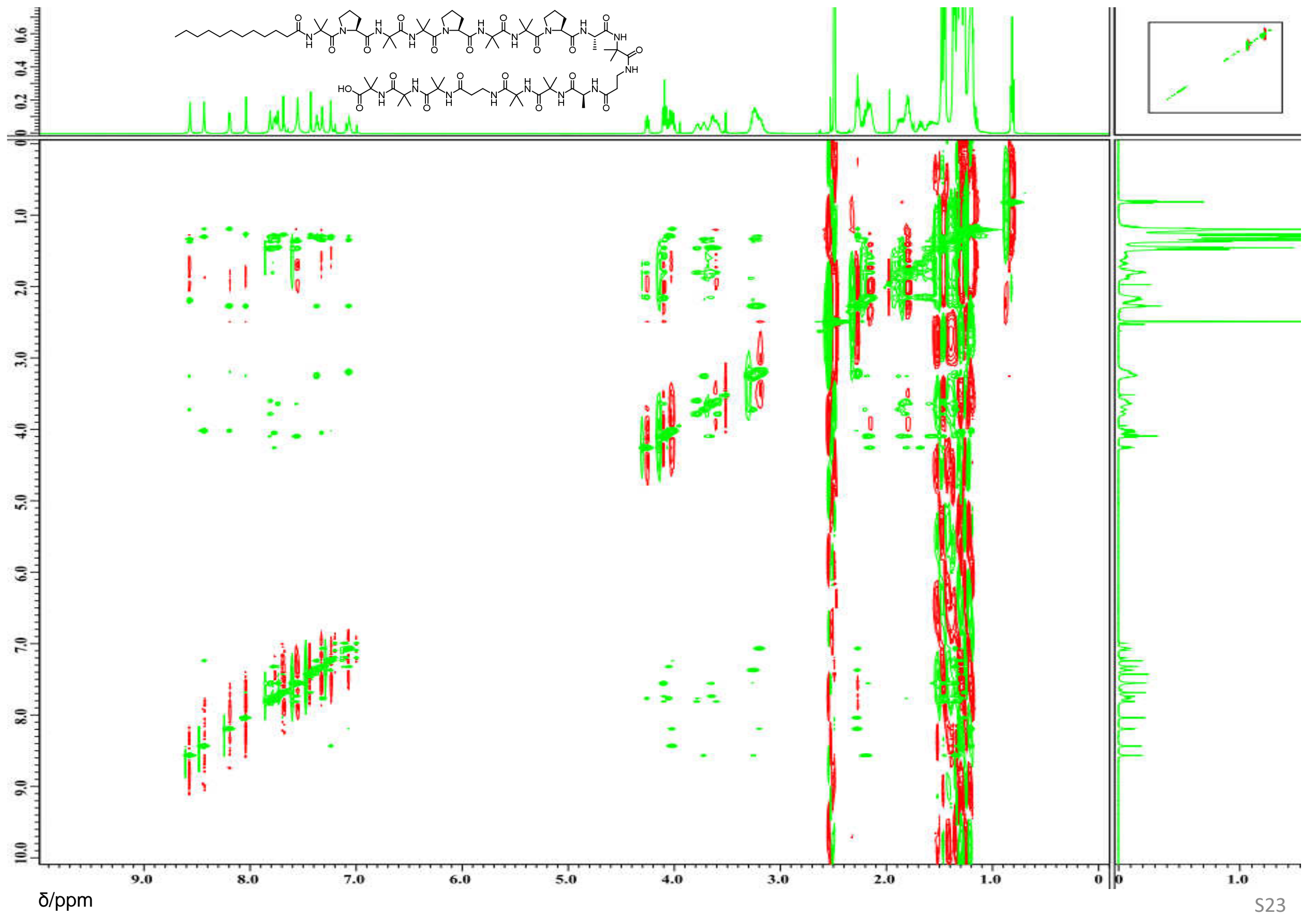


${ }^{1} \mathrm{H}$ NMR spectrum of synthesized myropeptin $\mathrm{A}_{1}(1)$ in DMSO- $d_{6}(500 \mathrm{MHz})$.

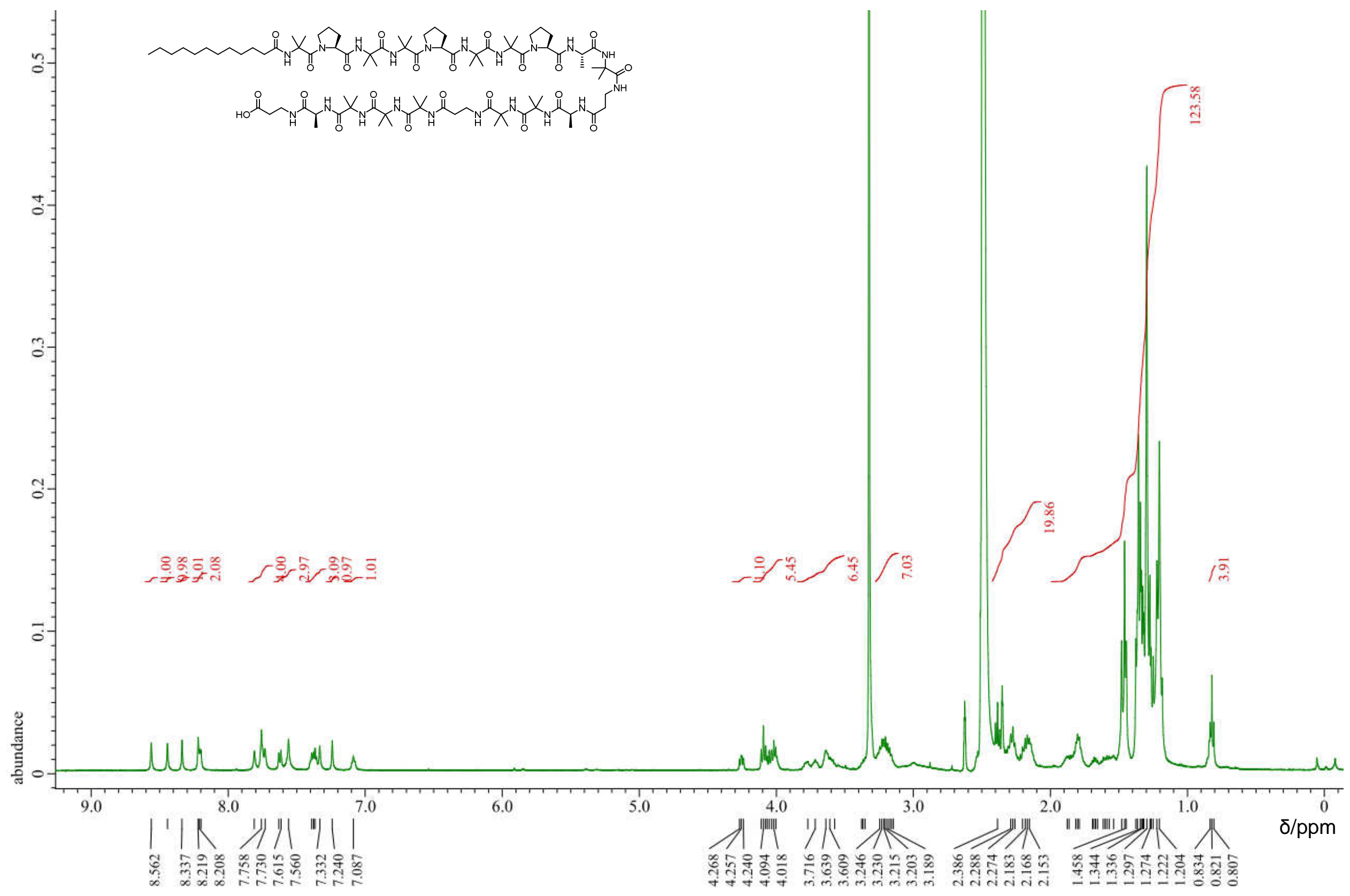


${ }^{1} \mathrm{H}$ NMR spectrum of dodecanoylAib in $\mathrm{CD}_{3} \mathrm{OD}(500 \mathrm{MHz})$.

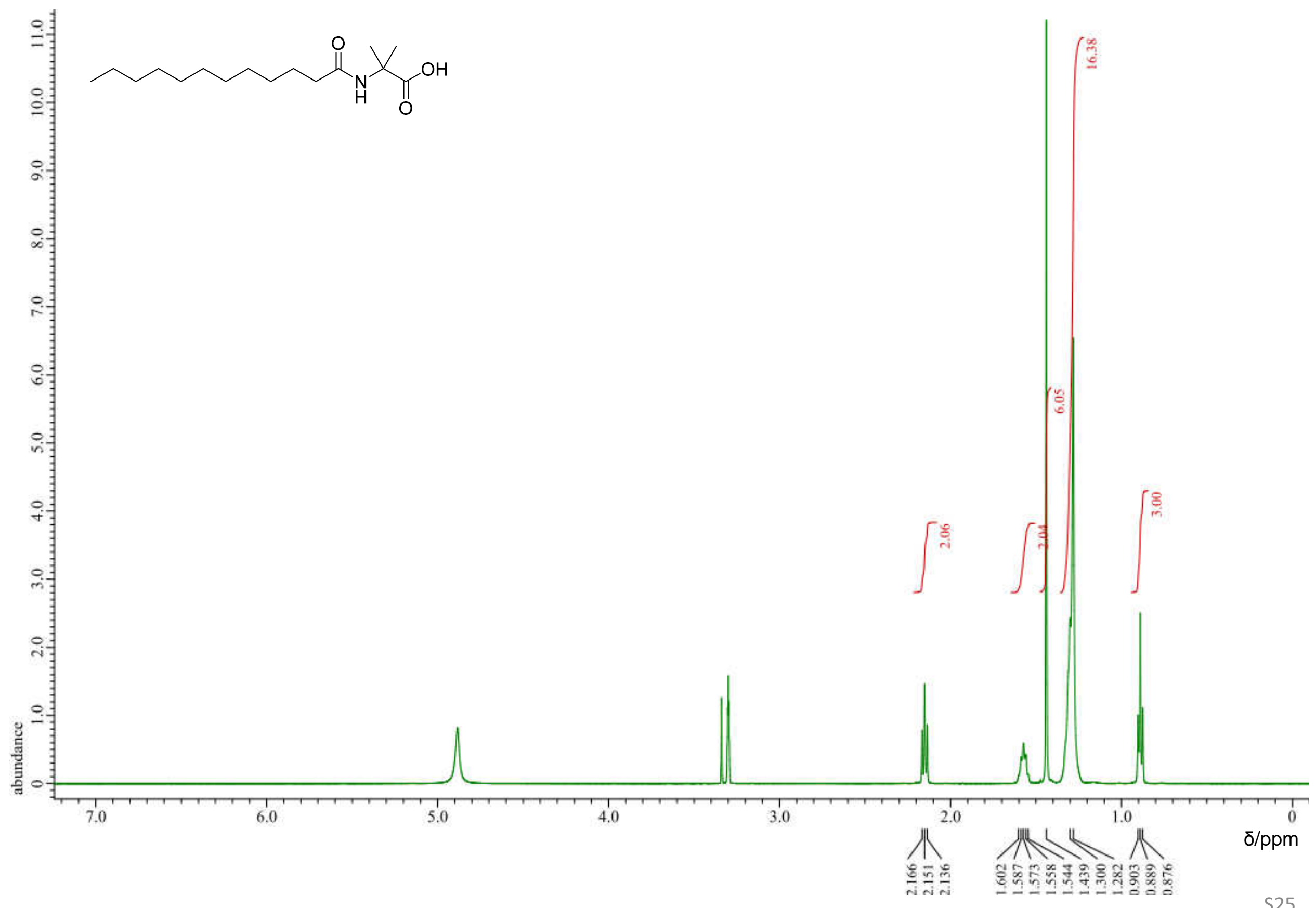


${ }^{13} \mathrm{C} \mathrm{NMR}$ spectrum of dodecanoylAib in $\mathrm{CD}_{3} \mathrm{OD}(125 \mathrm{MHz})$.

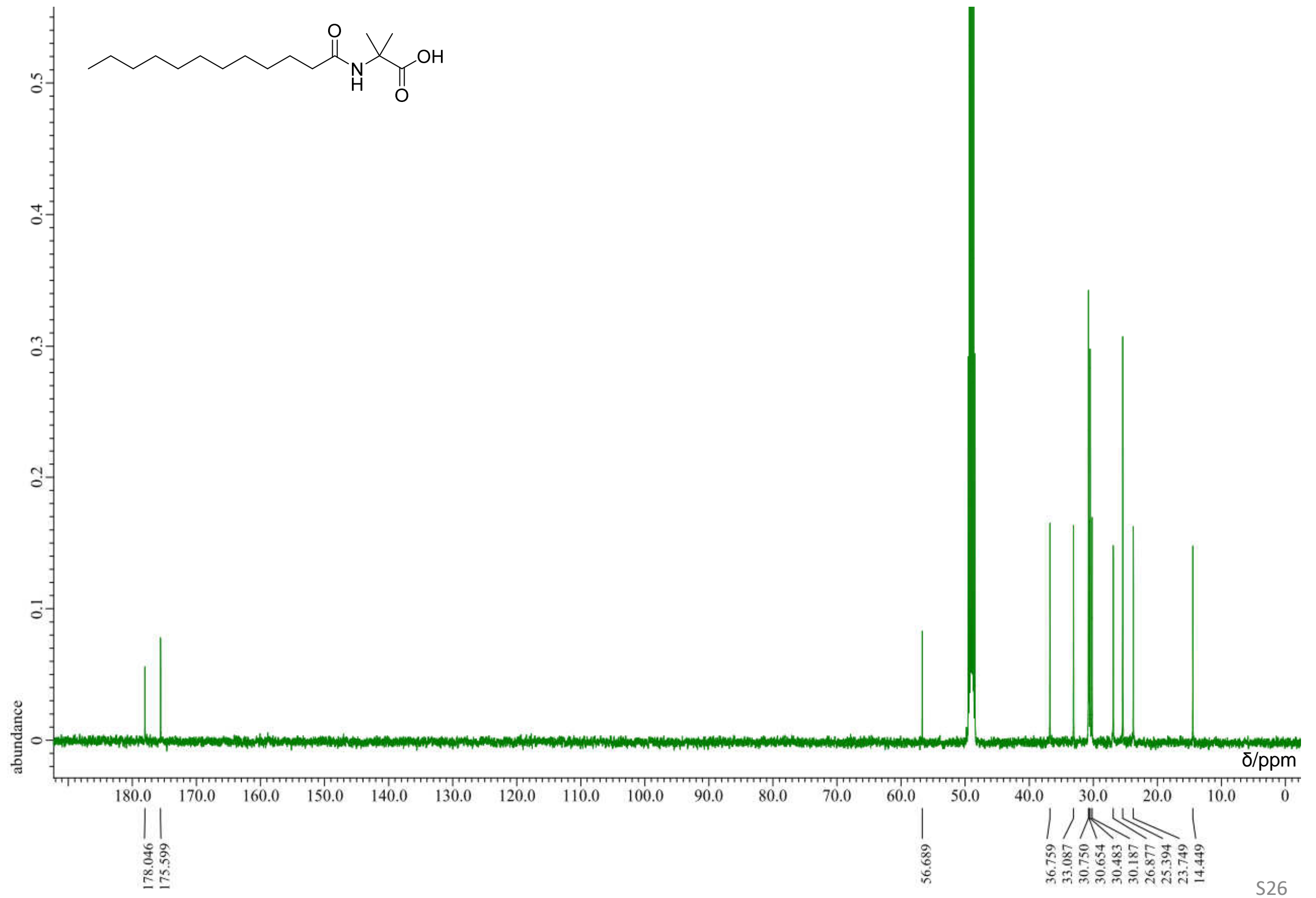


${ }^{1} \mathrm{H}$ NMR spectrum of L-Ala8AlaBn in $\mathrm{CD}_{3} \mathrm{OD}(500 \mathrm{MHz})$.

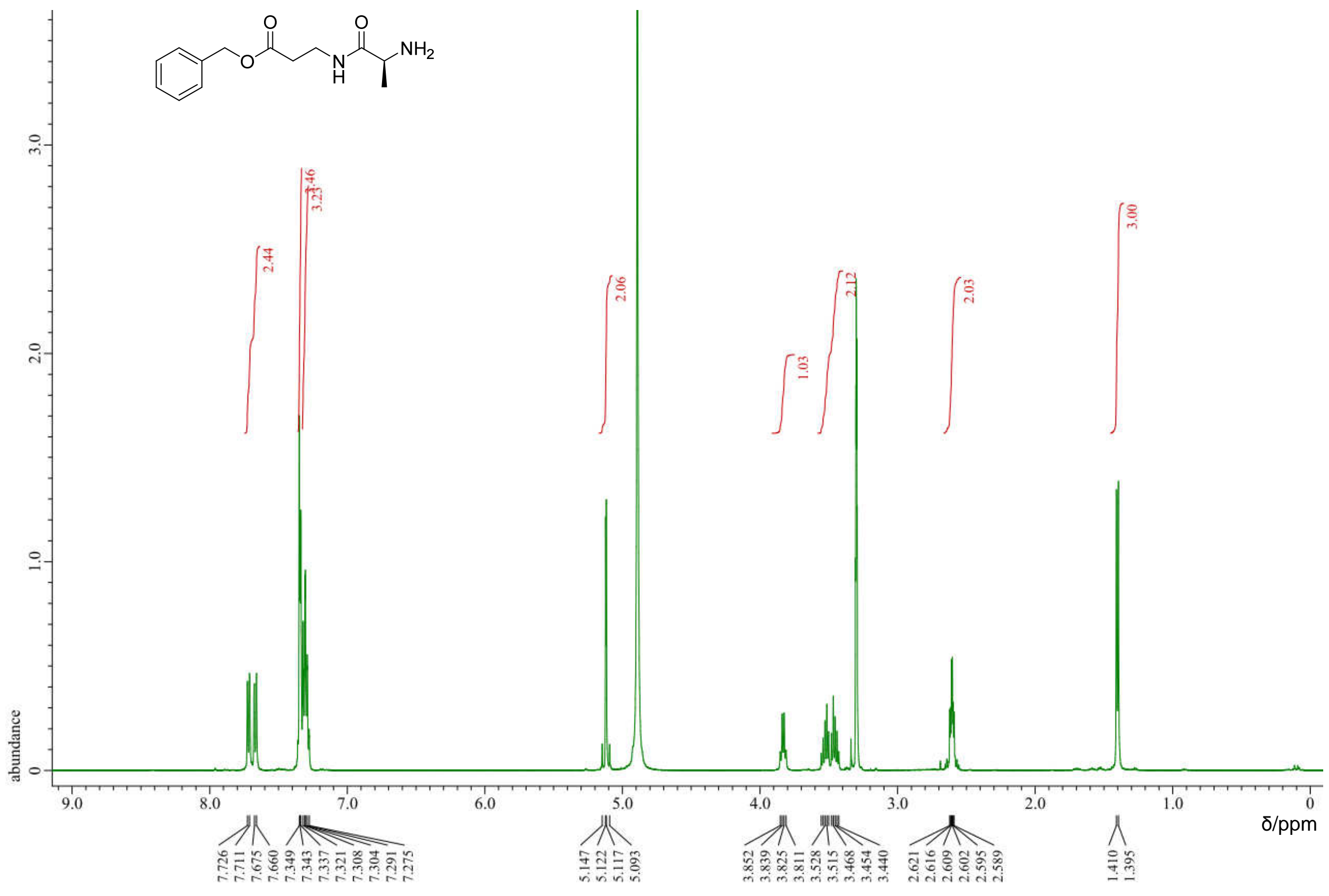


${ }^{13} \mathrm{C}$ NMR spectrum of L-AlabAlaBn in $\mathrm{CD}_{3} \mathrm{OD}(125 \mathrm{MHz})$.

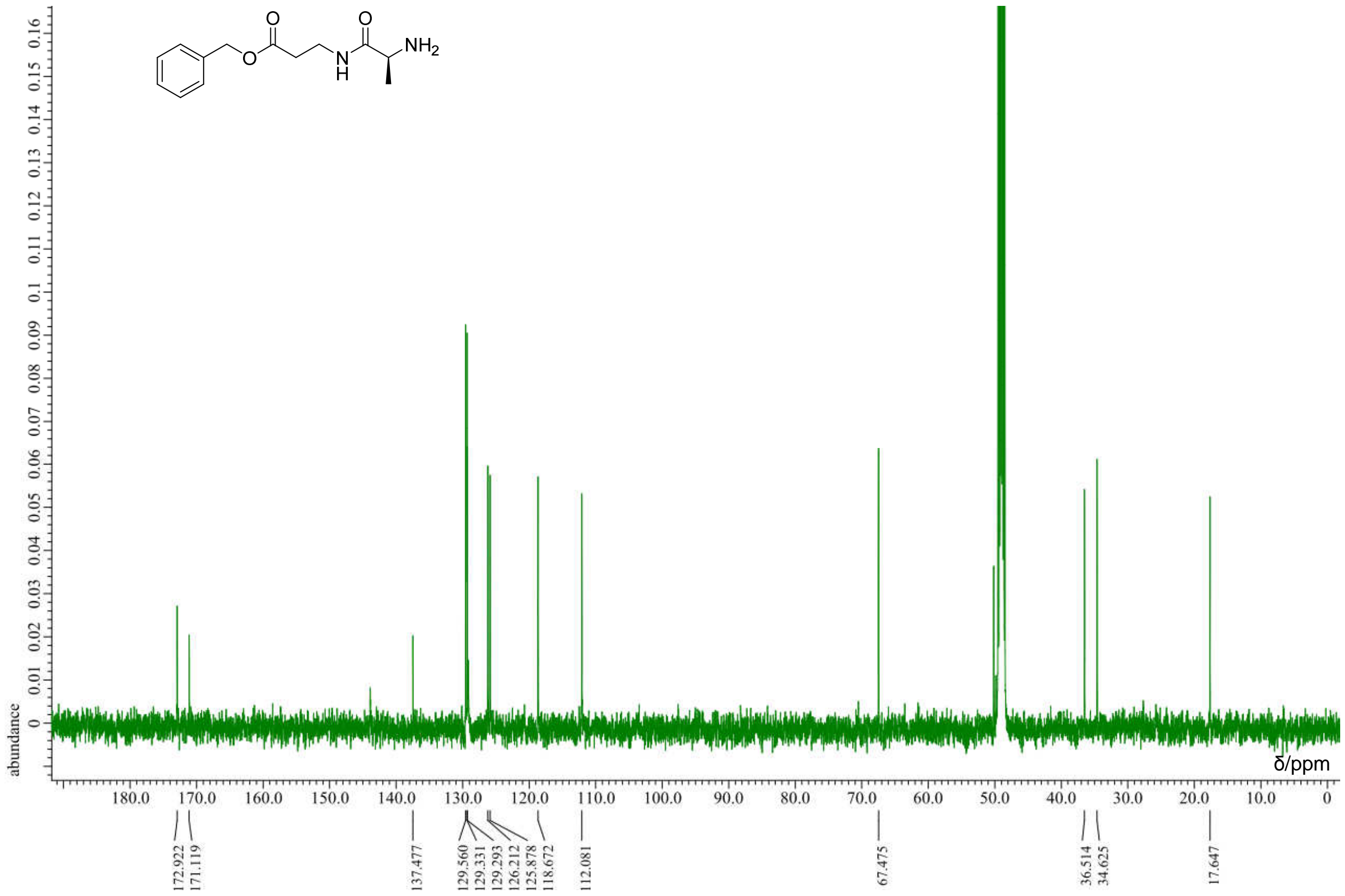

